\title{
Secondary aerosol formation from stress-induced biogenic emissions and possible climate feedbacks
}

\author{
Th. F. Mentel ${ }^{1}$, E. Kleist ${ }^{2}$, S. Andres ${ }^{1}$, M. Dal Maso ${ }^{1,3}$, $^{*}$, T. Hohaus ${ }^{1}$, A. Kiendler-Scharr ${ }^{1}$, Y. Rudich ${ }^{4}$, M. Springer ${ }^{1}$, \\ R. Tillmann ${ }^{1}$, R. Uerlings ${ }^{2}$, A. Wahner ${ }^{1}$, and J. Wildt ${ }^{2}$ \\ ${ }^{1}$ Institut für Energie- und Klimaforschung, IEK-8, Forschungszentrum Jülich, Germany \\ ${ }^{2}$ Institut für Bio- und Geowissenschaften, IBG-2, Forschungszentrum Jülich, Germany \\ ${ }^{3}$ Department of Physics, University of Helsinki, P.O. Box 48, 00014, Helsinki, Finland \\ ${ }^{4}$ Weizmann Institute of Science, Rehovot, 76100, Israel \\ *now: Dept. of Physics, Tampere University of Technology, 33101 Tampere, Finland
}

Correspondence to: Th. F. Mentel (t.mentel@fz-juelich.de)

Received: 2 February 2013 - Published in Atmos. Chem. Phys. Discuss.: 20 March 2013

Revised: 28 June 2013 - Accepted: 11 July 2013 - Published: 3 September 2013

\begin{abstract}
Atmospheric aerosols impact climate by scattering and absorbing solar radiation and by acting as ice and cloud condensation nuclei. Biogenic secondary organic aerosols (BSOAs) comprise an important component of atmospheric aerosols. Biogenic volatile organic compounds (BVOCs) emitted by vegetation are the source of BSOAs. Pathogens and insect attacks, heat waves and droughts can induce stress to plants that may impact their BVOC emissions, and hence the yield and type of formed BSOAs, and possibly their climatic effects. This raises questions of whether stress-induced changes in BSOA formation may attenuate or amplify effects of climate change. In this study we assess the potential impact of stress-induced BVOC emissions on BSOA formation for tree species typical for mixed deciduous and Boreal Eurasian forests. We studied the photochemical BSOA formation for plants infested by aphids in a laboratory setup under well-controlled conditions and applied in addition heat and drought stress. The results indicate that stress conditions substantially modify BSOA formation and yield. Stress-induced emissions of sesquiterpenes, methyl salicylate, and $\mathrm{C}_{17}$-BVOCs increase BSOA yields. Mixtures including these compounds exhibit BSOA yields between 17 and $33 \%$, significantly higher than mixtures containing mainly monoterpenes (4-6\% yield). Green leaf volatiles suppress SOA formation, presumably by scavenging $\mathrm{OH}$, similar to isoprene. By classifying emission types, stressors and BSOA formation potential, we discuss possible climatic feedbacks regarding aerosol effects. We conclude
\end{abstract}

that stress situations for plants due to climate change should be considered in climate-vegetation feedback mechanisms.

\section{Introduction}

Terrestrial vegetation is a key player in the biogeochemical cycles of carbon and water and thus a key player for Earth's climate (Carslaw et al., 2010). In addition vegetation constantly emits reactive biogenic volatile organic compounds (BVOCs) to the atmosphere, where they participate in atmospheric gas-phase chemistry and particle formation. At the global scale, BVOC emissions exceed anthropogenic VOC emissions by an order of magnitude (Guenther et al., 1995, 2012). BVOCs play an important role in atmospheric oxidation cycles; they affect ozone formation, the oxidation capacity of the atmosphere, and they are important players in new particle formation (Riipinen et al., 2011). BVOC (monoterpene) oxidation products generate biogenic secondary organic aerosols (BSOAs) and increase the number and size of aerosol particles (Tunved et al., 2006). Both attributes are significant with respect to the direct and the indirect effects of aerosols on the radiation budget of the Earth via scattering, absorption of sunlight and through modification of cloud properties (Tunved et al., 2008; Kerminen et al., 2005; Spracklen et al., 2008; Heald et al., 2008). Kulmala et al. (2004) and Goldstein et al. (2009) proposed that the increase in BSOA burden would cause a negative climate 
feedback through scattering of incoming solar radiation between the terrestrial ecosystem and the atmosphere, attenuating the temperature increase expected due to climate warming.

Climatic changes will alter the environmental conditions for vegetation (Sitch et al., 2007). Vegetation models predict that under future global climatic changes, forests in temperate and Boreal regions will flourish and spread, suggesting that this expansion will increase the annual global production of BVOCs and BSOAs (Lathière et al., 2005; Tsigaridis and Kanakidou, 2007). Climate models also predict frequent heat waves as well as changes in precipitation (Trenberth et al., 2007). It is noted that predictions of future BVOC emissions assume equilibrium between vegetation and climate (Lathière et al., 2005). However, noticeable climate change will appear already within the next decades, whereas vegetation propagates by only several tens of kilometers in $100 \mathrm{yr}$ (Chen et al., 2011). Thus the timescale of substantial climatic changes may be short compared to typical adaptation times of vegetation.

We thus hypothesize that vegetation in many regions will be forced out of the optimal living conditions as the plants will be exposed to more heat waves, dryness, pollution, insect outbreaks or various diseases due to climate change (Arneth et al., 2010). It is projected that such deviations will disturb the functioning of plants, denominated as stress to the plants. Our recent experiments suggest that it may not be sufficient to consider only isoprene and monoterpenes (MT) and BSOAs originating from those compounds in future (and current) climate scenarios. In addition stress-induced BVOC emissions as well as climate-change-induced impacts on BVOC emissions (Kleist et al., 2012) should be considered.

Phenomenological algorithms of BVOC emissions consider temperature and light intensity as the driving factors for the emission strengths of monoterpenes and isoprene (e.g. Guenther et al., 1993; Schuh et al., 1997; Kesselmeier and Staudt, 1999), but omit BVOC emissions in response to other stresses on plants (Heiden et al., 1999, 2003; Arneth and Niinemets, 2010; Peñuelas and Staudt, 2010; Loreto and Schnitzler, 2010). The latter emissions are termed stressinduced emissions (SIEs). SIEs are of transient character as they only appear during or after stress impacts. They consist of different BVOC classes including BVOCs synthesized within the phenylpropanoid pathway (e.g. Colquhoun et al., 2010, here denoted by "phenolic BVOCs"), BVOCs synthesized within the octadecanoid pathway (here denoted by "green leaf volatiles", GLV, e.g. Croft et al., 1993), and sesquiterpenes (SQT). Such BVOCs are emitted as a plant response to pathogen or herbivore attacks (e.g. Hopke et al., 1994; Boland et al., 1995). Upon atmospheric oxidation, SIEs may contribute significantly to BSOA formation similar to the constitutive emissions (Joutsensaari et al., 2005). Enhanced BSOA number formation during winter-spring tran- sition stress has also been observed in the field (Dal Maso et al., 2009).

Recently, we studied the effect of heat stress on constitutive emissions and SIEs in terms of de novo emissions and emissions from storage pools (Kleist et al., 2012). Here we survey which SIEs contribute to BSOA formation and to what extent they contribute to BSOA formation when included in a natural BVOC mix. To assess BSOA formation from SIEs we performed experiments with real plants in the Jülich Plant Atmosphere Chamber (JPAC). The plants were exposed to biotic stressors (aphid attack) and, in addition, to heat and drought stress in order to characterize the impact of abiotic stressors on BSOA formation.

\section{Experimental section}

Experiments were conducted in the JPAC facility. A detailed description of the chamber setup and its performance is given in Mentel et al. (2009). In short, the facility consists of three borosilicate glass chambers $\left(0.164 \mathrm{~m}^{3}, 1.150 \mathrm{~m}^{3}\right.$, and $1.450 \mathrm{~m}^{3}$ ) with Teflon floors. Each chamber is mounted in separate climate-controlled housing (adjustable between 10 and $50^{\circ} \mathrm{C}$ ). Either one of the two smaller chambers was used as the plant chamber. The large chamber was used as the reaction chamber for studying BSOA formation. Discharge lamps (HQI 400 W/D; Osram, Munich, Germany) simulated the solar light spectrum. At full illumination the photosynthetic photon flux density (PPFD) was $480 \mu \mathrm{mol} \mathrm{m}^{-2} \mathrm{~s}^{-1}$ in the $1.150 \mathrm{~m}^{3}$ chamber and $800 \mu \mathrm{mol} \mathrm{m}{ }^{-2} \mathrm{~s}^{-1}$ in the $0.164 \mathrm{~m}^{3}$ chamber.

Clean air was pumped through the plant chamber to take up BVOCs emitted by the plants. A fraction of the air leaving the plant chamber $\left(\approx 16 \mathrm{~L} \mathrm{~min}^{-1}\right)$ was fed into the reaction chamber. The reaction chamber had a separate inflow of $\approx 16 \mathrm{~L} \mathrm{~min}^{-1}$ to add ozone and humidified air. The residence time in the reaction chamber was about $45 \mathrm{~min}$.

The conditions in the reaction chamber were held constant for all experiments $\left(T=17 \pm 0.5^{\circ} \mathrm{C}, \mathrm{RH}=63 \pm 2 \%\right.$, $\left[\mathrm{O}_{3}\right]=85-90 \mathrm{ppb}$ without UV light, $\left.\left[\mathrm{NO}_{\mathrm{x}}\right]<300 \mathrm{ppt}\right)$. OH radicals were generated by ozone photolysis (internal UV lamp, Philips, TUV 40W, $\lambda_{\max }=254 \mathrm{~nm}, J\left(\mathrm{O}^{1} \mathrm{D}\right) \approx 2.9 \times$ $10^{-3} \mathrm{~s}^{-1}$ ) and subsequent reaction of $\mathrm{O}^{1} \mathrm{D}$ with water. $\mathrm{OH}$ radicals were generated when the BVOC concentrations in the reaction chamber had reached a steady state. $\mathrm{OH}$ radical concentrations ranged from $10^{7}$ to $10^{8} \mathrm{~cm}^{-3}$. The presence of $\mathrm{OH}$ radicals induced new particle formation. Particle concentration (particle diameter $d_{\mathrm{p}}>7 \mathrm{~nm}$ ) and size distribution $\left(15 \mathrm{~nm}<d_{\mathrm{p}}<700 \mathrm{~nm}\right)$ were measured by a condensation particle counter (CPC TSI3022A) and a scanning mobility particle sizer (SMPS TSI3071+TSI3025A), respectively.

BVOC concentrations were measured at the outlet air of the plant chamber and the reaction chamber using GC-MS (Heiden et al., 1999). OH concentrations were determined by the decrease of deuterated cyclohexane $\left(\mathrm{C}_{6} \mathrm{D}_{12}\right)$ added to 
Table 1. Overview over experiments with trees and control experiments.

\begin{tabular}{llll}
\hline No & Purpose of experiment & Plants used & Remarks \\
\hline 1 & $\begin{array}{l}\text { Impact of biotic SIEs on BSOA } \\
\text { formation }\end{array}$ & $\begin{array}{l}\text { Silver birch, Scots pine, } \\
\text { Norway spruce }\end{array}$ & $\begin{array}{l}\text { High degree of aphid } \\
\text { infestation of spruce }\end{array}$ \\
\hline $1 \mathrm{c}$ & $\begin{array}{l}\text { Contribution of MeSa to BSOA } \\
\text { formation }\end{array}$ & $\begin{array}{l}\text { Control experiment with } \\
\text { BVOCs from diffusion source }\end{array}$ & MeSa addition to $\alpha$-pinene \\
\hline 2 & $\begin{array}{l}\text { Impact of heat stress on BSOA } \\
\text { formation from biotic SIEs }\end{array}$ & Norway spruce & $\begin{array}{l}\text { High degree of aphid } \\
\text { infestation }\end{array}$ \\
\hline 3 & $\begin{array}{l}\text { Impact of drought stress on } \\
\text { BSOA formation (interaction of } \\
\text { GLV emissions and emissions } \\
\text { of C } 17 \text {-BVOCs) }\end{array}$ & $\begin{array}{l}\text { Silver birch, European beech, } \\
\text { Norway spruce }\end{array}$ & $\begin{array}{l}\text { Spruce infested by } \\
\text { Cinara pilicornis }\end{array}$ \\
\hline $3 \mathrm{c}$ & $\begin{array}{l}\text { Impact of green leaf volatiles } \\
\text { on BSOA formation }\end{array}$ & $\begin{array}{l}\text { Control experiment with } \\
\text { BVOCs from diffusion source }\end{array}$ & $\begin{array}{l}\text { (Z)-3-hexenol addition to } \\
\alpha \text {-pinene }\end{array}$ \\
\hline
\end{tabular}

the reaction chamber (Kiendler-Scharr et al., 2009). Calibration of the GC-MS was conducted as described in Heiden et al. (2003). To calibrate the $\mathrm{C}_{17}$-BVOCs emitted from insectinfested spruce we used 8-heptadecene (Fluka, GC purity) as a surrogate for emitted $\mathrm{C}_{17}$-compounds.

After changing the conditions in the plant chamber we allocated $8 \mathrm{~h}$ for establishing new steady state conditions in the reaction chamber before the next experiment. Particle formation was studied once a day with time intervals longer than $12 \mathrm{~h}$ with UV off between two particle events. In these periods the reaction chamber was flushed and conditioned by the plant chamber flow and the conditioning flow, each consisting of $16 \mathrm{~L} \mathrm{~min}^{-1}$ of particle free air. Since the residence time in the reaction chamber is about $45 \mathrm{~min}$, we thus allowed more than 10 e-folding times to re-condition the chamber and to remove the reaction mix from the previous experiment including particles.

The BSOA yields were determined as established in detail in Mentel et al. (2009). By changing the conditions in the plant chamber the concentration of BVOCs in the reaction chamber was varied. The formation of BSOA mass was determined as a function of the BVOC mass that reacted with $\mathrm{OH}$ and $\mathrm{O}_{3}$. We observed linear relations between BSOA formation and BVOC consumption in the applied concentration range (see later Figs. 2, 3, 5, and 7). Under these conditions the slope obtained by regression analysis is defined as the incremental mass yield.

The incremental mass yield quantifies the efficiency to convert BVOC mass by gas-phase oxidation into particulate matter (BSOA). The incremental mass yield is independent of the amount of consumed BVOCs for the conditions here, but the actual obtained BSOA mass is of course proportional to the amount of BVOCs which is available and is consumed. However, the incremental mass yield may depend on the emission pattern because different BVOCs can exhibit different incremental yields.
We performed five experiments - three with plants and two control experiments. These experiments are summarized in Table 1. For Experiments \#1, \#2, and \#3 with plants we used three- to four-year-old seedlings of spruce (Picea abies L.), pine (Pinus sylvestris L.), beech (Fagus sylvatica L.), and birch (Betula pendula L.). The plants were stored near a natural forest before the measurements to obtain realistic conditions with all the impacts that plants experience in their natural environment. The plants suffered from typical diseases as insect or pathogen attacks and featured SIEs when they were introduced into the plant chamber. Up to four plants were introduced together into the plant chamber (see Table 1).

In Experiment \#1 we used seedlings of one Silver birch (Betula pendula L.), one Scots pine (Pinus sylvestris L.), and one Norway spruce (Picea abies L.) together as the BVOC source. The spruce showed a high degree of aphid infestation. No infestation was visible for the other trees, but they also may have been infested. The plants were introduced into the $1.150 \mathrm{~m}^{3}$ plant chamber, acclimated for one day and investigated over 18 days. A diurnal cycle of light was applied: $13 \mathrm{~h}$ illumination, $9 \mathrm{~h}$ darkness and simulations of twilight for $1 \mathrm{~h}$ in the morning and evening, respectively. The light intensity (PPFD) was normally set to $480 \mu \mathrm{mol} \mathrm{m}^{-2} \mathrm{~s}^{-1}$ during the periods of illumination. To vary the emission strength, the plant chamber temperature was set to either 15 or $20^{\circ} \mathrm{C}$ at different days. PPFD was varied from day to day in steps of $120 \mu \mathrm{mol} \mathrm{m}^{-2} \mathrm{~s}^{-1}$ at $T=15^{\circ} \mathrm{C}$ on several occasions.

In Experiment \#2 we investigated an individual Norway spruce severely infested by aphids. This plant was investigated for 11 days in total. During the first five days, moderate temperatures were applied to the plant (days -5 to -1 , $T=15$ or $20^{\circ} \mathrm{C}$, Table 2). Higher temperatures of $35^{\circ} \mathrm{C}$ and $30^{\circ} \mathrm{C}$ were applied on day 0 and day 1 , respectively. During the remaining 4 days, moderate temperatures of $20^{\circ} \mathrm{C}$ were applied (days 2 to 5). During the entire measurement period the diurnal light cycle was the same with PPFD = 
Table 2. Plant chamber temperatures and MT/SQT concentration ratios $\left(\left[\mu \mathrm{g} \mathrm{m}^{-3}\right] /\left[\mu \mathrm{gm}{ }^{-3}\right]\right)$ during Experiment \#2 with Norway spruce. Days relative to the day of heat stress application at day 0 . Note that the needle temperature was about $4{ }^{\circ} \mathrm{C}$ higher than the listed plant chamber temperature during periods of illumination (compare Kleist et al., 2012).

\begin{tabular}{lrrrrrrrrrrr}
\hline Day & -5 & -4 & -3 & -2 & -1 & 0 & 1 & 2 & 3 & 4 & 5 \\
\hline$T\left[{ }^{\circ} \mathrm{C}\right]$ & 20 & 15 & 15 & 20 & 25 & 35 & 30 & 20 & 20 & 20 & 20 \\
$\mathrm{MT} / \mathrm{SQT}$ & 0.4 & 0.27 & 0.32 & 0.49 & 1.7 & 19 & 15 & $>100$ & 66 & 81 & $>100$ \\
\hline
\end{tabular}

$480 / 0 \mu \mathrm{mol} \mathrm{m}^{-2} \mathrm{~s}^{-1}$ during periods of illumination/darkness. Table 2 lists the temperatures together with the measured MT / SQT ratios $\left(\left[\mu \mathrm{g} \mathrm{m}^{-3}\right] /\left[\mu \mathrm{g} \mathrm{m}^{-3}\right]\right)$.

In Experiment \#3 we used a set of four trees typical for the central European mixed forest (one spruce, one birch and two beech seedlings). The spruce was infested by the aphid Cinara pilicornis and emitted long-chained $\mathrm{C}_{17}$-alkenes. The birch did not show visible symptoms of injury, but both beech seedlings showed symptoms of drought stress visible by leaf curling. We did not irrigate the soil for 5 days in order to apply drought stress in addition to the infestation. The diurnal light cycle was PPFD $=480 / 0 \mu \mathrm{mol} \mathrm{m}^{-2} \mathrm{~s}^{-1}$ during periods of illumination/darkness. Plant chamber temperature was held constant at $20^{\circ} \mathrm{C}$ except for the last day, when it was increased to $25^{\circ} \mathrm{C}$.

For the control Experiments \#1c and \#3c the substances were evaporated from diffusion sources, diluted by synthetic air and continuously flushed into the reaction chamber. As for plant emissions BSOA formation was induced by ozone photolysis in the presence of water and subsequent $\mathrm{OH}$ formation. UV light was switched on and particle formation was induced when steady state concentrations were reached after three hours. Conditions in the reaction chamber were kept identical to those of the experiments with the plants.

In control Experiment \#1c we determined the impact of methyl salicylate (MeSa) on BSOA formation. We added $\mathrm{MeSa}$, deuterated cyclohexane-d12 and $\alpha$-pinene to the reaction chamber. Concentrations of $\alpha$-pinene and cyclohexane$\mathrm{d} 12$ were held constant, and the steady state concentration of $\alpha$-pinene would have been $27 \pm 3 \mu \mathrm{g} \mathrm{m}^{-3}(4.8 \pm 0.6 \mathrm{ppb})$ if ozone reactions had been absent; cyclohexane-d12 concentrations were $1.5 \mu \mathrm{g} \mathrm{m}^{-3}(\sim 0.4 \mathrm{ppb})$. MeSa concentrations were varied between 0 and $55 \mu \mathrm{g} \mathrm{m}^{-3}$ ( 0 to $8.8 \mathrm{ppb}$ ). BSOA formation was induced by oxidation of the reaction mix by $\mathrm{OH}$ radicals $\left([\mathrm{OH}] \sim 6 \times 10^{7} \mathrm{~cm}^{-3}\right.$ (see Fig. 3), $\left[\mathrm{O}_{3}\right] 40-$ $50 \mathrm{ppb}$ with UV light switched on and $\left[\mathrm{O}_{3}\right]=85-90 \mathrm{ppb}$ with UV light switched off, reaction chamber temperature $\left.17 \pm 0.5^{\circ} \mathrm{C}, \mathrm{RH}=63 \pm 2 \%\right)$. $\mathrm{OH}$ concentrations were determined from the difference of cyclohexane-d12 concentrations at chamber outlet with and without the UV light. Less than $60 \%$ of the added MeSa reacted with $\mathrm{OH}$ radicals due to the low reactivity of MeSa.

In control Experiment \#3c we investigated the drastic effect of GLV observed in Experiment \#3 induced by drought stress. Again we added $\alpha$-pinene $\left(43 \pm 4 \mu \mathrm{g} \mathrm{m}^{-3}\right)$ and cyclohexane-d12 to trace $\mathrm{OH}$ concentrations to the reaction chamber. As a typical GLV we added (Z)-3-hexenol to the chamber in varying concentrations at otherwise unchanged conditions. Experiments were conducted from day to day with (Z)-3-hexenol concentrations varying from 0 to $48 \mu \mathrm{g} \mathrm{m}^{-3}$. BSOA formation was induced by oxidation of $\alpha$ pinene by $\mathrm{OH}\left([\mathrm{OH}] \sim 6 \times 10^{7}-1.6 \times 10^{7} \mathrm{~cm}^{-3},\left[\mathrm{O}_{3}\right]=85-\right.$ $90 \mathrm{ppb}$ in the absence and 40-50 ppb in the presence of UV light, respectively, $T=17 \pm 0.5^{\circ} \mathrm{C}, \mathrm{RH}=63 \pm 2 \%$ ).

For the determination of incremental mass yields one needs to know the amount of chemically consumed BVOCs. This quantity was directly obtained by comparing the concentrations of the reactants entering and leaving the reaction chamber. Generally, more than $98 \%$ of the MT and SQT entering the reaction chamber were oxidized at the typical $\mathrm{OH}$ and $\mathrm{O}_{3}$ concentrations in the reaction chamber. In these cases the chemical consumption was set equal to the input amount. For MeSa, which reacted to less than $60 \%$, the chemical consumption was calculated from the difference of MeSa concentrations with and without UV light switched on.

Maximum BSOA mass was reached after $1-2 \mathrm{~h}$, depending on the concentrations of BVOCs and oxidants. The observed maximal particle mass was corrected for the loss by outflow and plotted versus the BVOC consumption in the reaction chamber as described in Mentel et al. (2009). As the basis for BVOC consumption we used the mass (in $\mu \mathrm{g} \mathrm{m}^{-3}$ ) summed up over all detected BVOCs, independent of their biosynthetic origin.

It has to be noted that uncertainties for the yields given here were determined from statistical errors only. Possible systematic errors such as erroneous calibration (GC-MS data: $\pm 15 \%$ for MT and $\pm 20 \%$ for SQT) were not included. All measurements were performed under low- $\mathrm{NO}_{\mathrm{x}}$ conditions $\left(\mathrm{NO}_{\mathrm{x}}<300 \mathrm{ppt}\right)$.

\section{Results}

\subsection{Experiment \#1: BSOA formation from sesquiterpenes and methyl salicylate}

Under the conditions of Experiment \#1, the plants emitted mainly SQT and phenolic BVOCs, indicating that the main portion of the emissions was induced by biotic stress, most probably due to the insect infestation. Considering that there was no active control on the stress impacts imposed 

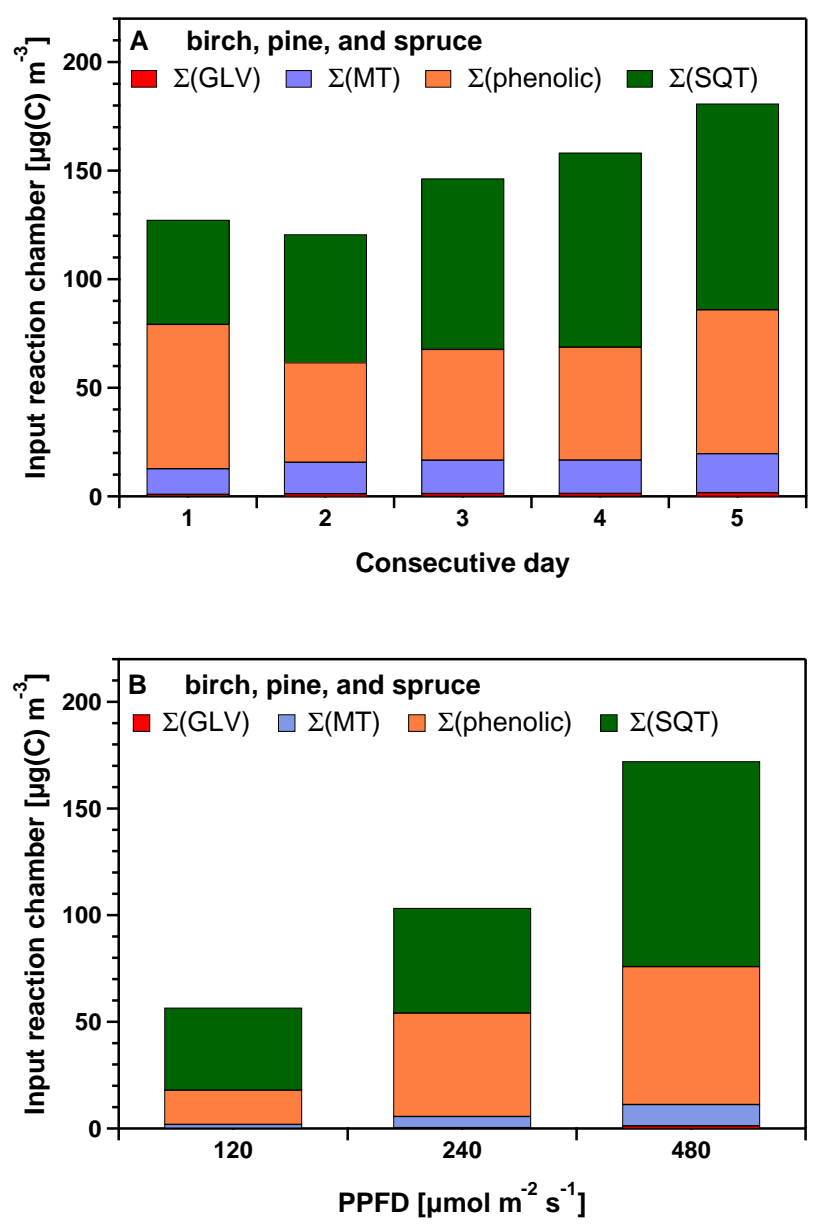

Fig. 1. BVOC concentrations at the inlet of the reaction chamber determined in Experiment \#1. Concentrations were averaged for $4 \mathrm{~h}$ before particle formation was induced in the reaction chamber. GLV $=$ green leaf volatiles, mainly $\mathrm{C}_{6}$-alcohols and -aldehydes with significant emissions only at day $5, \mathrm{MT}=$ monoterpenes, phenolic $=$ phenolic BVOCs originating downstream of the shikimate pathway, $\mathrm{SQT}=$ sesquiterpenes. (A) At constant PPFD $=480 \mu \mathrm{mol} \mathrm{m}{ }^{-2} \mathrm{~s}^{-1}$ and constant plant chamber temperature $=15^{\circ} \mathrm{C}$, during a measurement period of five consecutive days. (B) At different PPFD and constant plant chamber temperature $=15 \pm 0.5^{\circ} \mathrm{C}$. Note that the pattern depicted for PPFD $=480 \mu \mathrm{mol} \mathrm{m}^{-2} \mathrm{~s}^{-1}$ is not included in (A).

by the insect infestation, both emission strengths as well as the emission patterns were fairly stable for constant temperature and constant PPFD (Fig. 1a). The ratios SQT/MT and phenolic/MT covered ranges of 4.1-5.8 (average = $4.8 \pm 0.8$ ) and 3.2-5.6 (average $=3.8 \pm 1.0$ ), respectively. Variation of temperature changed essentially only the emission strengths. SQT and phenolic BVOCs are de novo emissions and the emission strengths also depend on PPFD (Fig. 1b, Kleist et al., 2012). This observation is in agreement with the results of Gouinguene and Turlings (2002).

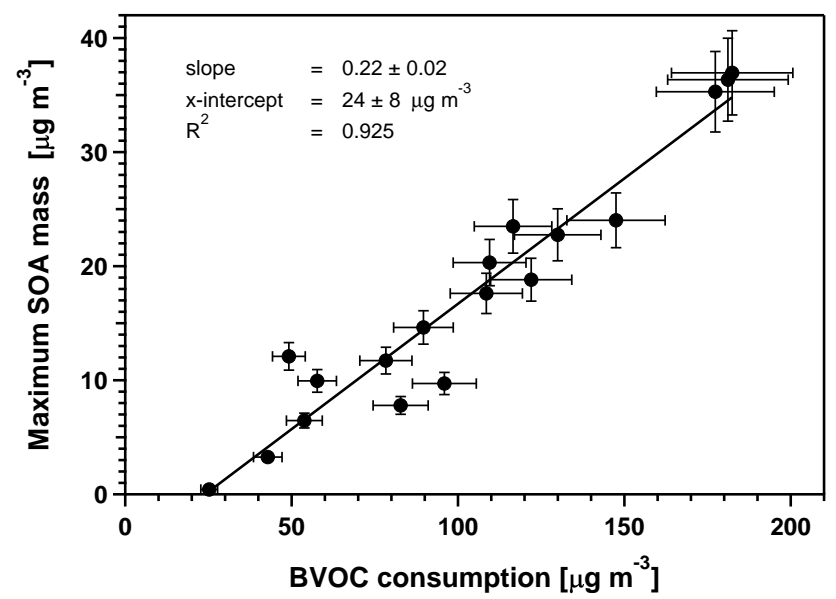

Fig. 2. Maximum BSOA mass produced through $\mathrm{OH}$ oxidation of BVOCs emitted from a birch, a pine and a spruce, the lattermost infested by aphids (Experiment \#1). The linear regression line indicates an incremental yield of $22 \pm 2 \%$. The error bars represent relative errors of $\pm 5 \%$ for the SMPS-based BSOA mass and $\pm 10 \%$ for the BVOC consumption according to GC calibration errors.

For $120 \leq \mathrm{PPFD} \leq 480 \mu \mathrm{mol} \mathrm{m}{ }^{-2} \mathrm{~s}^{-1} \mathrm{SQT} / \mathrm{MT}$ and phenolic / MT varied from 9 to 21 and from 6 to 9, respectively.

In Experiment \#1 with the infested spruce, SQT contributed up to $56 \%$ to the total emissions and phenolic BVOCs up to $44 \%$. MT $(\leq 10 \%)$ and GLV $(\leq 1 \%)$ were only minor fractions of the mix of reactive BVOCs. The dominating SQT were $\alpha$-farnesene $(\sim 27 \%)$ and $\beta$-farnesene ( $~ 66 \%)$. About $95 \%$ of the phenolic BVOCs were methyl salicylate (MeSa). Other phenolic BVOCs that were emitted in minor amounts were compounds such as methyl benzoate $(\sim 1 \%)$ and benzyl benzoate $(\sim 0.7 \%)$. Table 3 lists the BVOCs found in the emission mix, their concentrations and their contribution to the total VOC emissions from this set of plants.

SOA formation was observed only in the presence of $\mathrm{OH}$ as for unstressed plants (Mentel et al., 2009). Ozonolysis alone did not lead to SOA formation. A $22 \pm 2 \%$ incremental SOA mass yield was determined for this mixture from the slope of linear fit in Fig 2. This incremental yield is significantly higher than the 4-6\% value measured for a mixture consisting of MT only (Mentel et al., 2009; Lang-Yona et al., 2010), but is similar to that obtained for stressed transgenic poplar plants (Kiendler-Scharr et al., 2012) that exhibited a similar emission pattern as the plants used here. The positive $x$-intercept in Fig. 2 and in similar plots in the following indicates the nucleation threshold in JPAC (Mentel et al., 2009) and is not further considered here.

It was impossible to identify the contribution of the different BVOCs on BSOA formation because the plants coemitted SQT and MeSa. Therefore we determined independently the SOA yield for MeSa in control Experiment \#1c using $\alpha$-pinene and MeSa from artificial sources. The $\alpha$-pinene 
Table 3. Major BVOCs emitted from the set of plants used in Experiment \#1 (data is for day 5 in Fig. 1). BVOCs with concentrations above $0.1 \mu \mathrm{g} \mathrm{m}^{-3}$ are listed explicitly. Concentrations listed for the sum of BVOC classes (bold) include also BVOCs with concentrations below $0.1 \mu \mathrm{g} \mathrm{m}^{-3}$.

\begin{tabular}{|c|c|c|c|}
\hline BVOC & Class & Conc. $\left[\mu \mathrm{g} \mathrm{m}^{-3}\right]$ & Contribution [\%] \\
\hline Isoprene & C5 & 0.71 & 0.4 \\
\hline (Z)-3-hexenol & GLV & 0.16 & 0.09 \\
\hline (Z)-3-hexenylacetate & GLV & 1.5 & 0.8 \\
\hline Sum green leaf volatiles & GLV & 2.01 & 1.1 \\
\hline$\alpha$-pinene & MT & 1.05 & 0.57 \\
\hline Camphene & MT & 0.21 & 0.11 \\
\hline Sabinene & MT & 0.14 & 0.08 \\
\hline Myrcene & MT & 0.77 & 0.42 \\
\hline$\beta$-pinene & MT & 0.16 & 0.09 \\
\hline$\Delta^{3}$ carene & MT & 0.68 & 0.37 \\
\hline Limonene & MT & 0.53 & 0.29 \\
\hline$\beta$-phellandrene + cis-ocimene $^{\mathrm{a}}$ & MT & 0.28 & 0.15 \\
\hline$(E)$ - $\beta$-ocimene & MT & 4.57 & 2.5 \\
\hline Terpinolene & MT & 3.22 & 1.7 \\
\hline Alloocimene & MT & 2.15 & 1.2 \\
\hline 1,8-cineole & MT & 0.77 & 0.4 \\
\hline $\mathrm{DMNT}^{\mathrm{b}}$ & $\mathrm{MT}^{\circ}$ & 2.07 & 1.1 \\
\hline Sum monoterpenes & MT & 17.9 & 9.7 \\
\hline$(E)-\beta$-caryophyllene $\mathrm{c}^{\mathrm{c}}$ & SQT & 0.11 & 0.06 \\
\hline$(E)$ - $\alpha$-bergamotene & SQT & 0.13 & 0.07 \\
\hline$(E)-\beta$-farnesene & SQT & 65.5 & 35.5 \\
\hline$\alpha-$ curcumene $^{\mathrm{c}}$ & SQT & 0.14 & 0.08 \\
\hline$(E)$-farnesene $e^{c}$ & SQT & 0.26 & 0.14 \\
\hline$\beta$-bisabolene & SQT & 0.18 & 0.1 \\
\hline$(E, E)$ - $\alpha$-farnesene & SQT & 30.1 & 16.3 \\
\hline$\Delta$-cadinene & SQT & 0.17 & 0.09 \\
\hline (Z)- $\alpha$-bisabolene & SQT & 4.37 & 2.4 \\
\hline Sum sesquiterpenes & SQT & 104 & 56.3 \\
\hline $\mathrm{MeSa}$ & Phen. & 48 & 26 \\
\hline Benzoic acid methyl ester & Phen. & 1.9 & 1.0 \\
\hline Benzyl benzoate & Phen. & 0.5 & 0.27 \\
\hline Sum phenolic BVOCs & Phen. & 59.9 & 32.4 \\
\hline Other BVOCs ${ }^{\mathrm{d}}$ & & 0.22 & 0.1 \\
\hline
\end{tabular}

was used as a representative for constitutive SOA precursors to induce SOA formation. Its concentration was held constant at $27 \mu \mathrm{g} \mathrm{m}^{-3}$ (4.5 ppb), while MeSa concentrations were varied between 0 and $55 \mu \mathrm{g} \mathrm{m}^{-3}$ ( 0 to $8.8 \mathrm{ppb}$ ). The incremental mass yield of the $\alpha$-pinene/MeSa mixture was determined to $20 \pm 3 \%$ (slope in Fig. 3). Since only MeSa concentrations were varied, the incremental yield is due to MeSa. The $\mathrm{OH}$ concentrations were not affected much by the increasing MeSa concentrations due to the low reactivity of MeSa (Fig. 3). The incremental yield for MeSa has the same magnitude as that obtained with the mix of MeSa and SQT emitted from the set of plants in Experiment \#1, suggesting that both MeSa and SQT have similar BSOA yields of about $20 \%$.

\subsection{Experiment \#2: impacts of heat stress on BSOA formation}

Figure 4 shows the concentrations of different BVOC classes at the inlet of the reaction chamber during Experiment \#2 with the infested spruce over 11 days. The emission strengths of SQT and MT decreased over the first 4 days (days -5 to -2 in Table 2 and Fig. 4) and also the emission pattern was not strictly constant. During the first 4 days, SQT emissions were higher than MT emissions. Only on day -1 , when the temperature of the plant chamber increased to $25^{\circ} \mathrm{C}$, were the MT emissions somewhat higher than SQT emissions. 


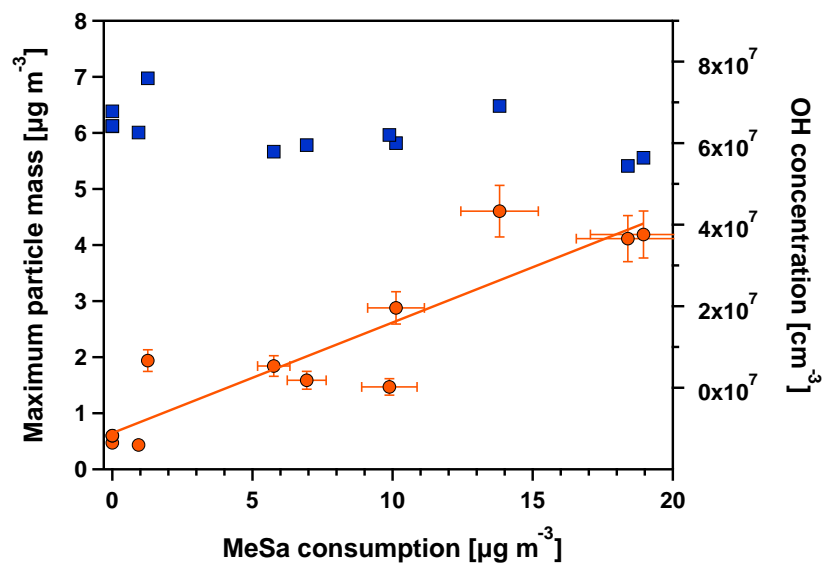

Fig. 3. Maximum BSOA mass (orange circles, left scale) and $\mathrm{OH}$ concentrations (blue squares, right scale) upon addition of up to $55 \mu \mathrm{g} \mathrm{m}^{-3}$ of MeSa to the reaction chamber in Experiment \#1c. The $\alpha$-pinene concentration was held constant at $27 \pm 3 \mu \mathrm{g} \mathrm{m}^{-3}$. The line shows the result of linear regression analysis giving the yield of $20 \pm 3 \%\left(R^{2}=0.83\right)$.

When the spruce was exposed to heat stress of $T=35^{\circ} \mathrm{C}$ for $9 \mathrm{~h}$ on day 0 and $T=30^{\circ} \mathrm{C}$ for $10 \mathrm{~h}$ on day 1 , we observed a strong increase of MT emissions due to a damage of the resin ducts where MT are stored. SQT emissions changed significantly less during the heat stress (compare Kleist et al., 2012).

Following the heat stress, the plant was held at $20^{\circ} \mathrm{C}$ for another 4 days (day 2-day 5), during which SQT emissions decreased each day until they reached the instrumental detection limit on day 3. The heat stress had caused a decline of SQT. The MT emissions also decreased from day 2 to day 5 , possible due to plant internal repair of pool damage.

BSOA formation was measured during the whole period of 11 days. For the days -5 to day -2 with MT / SQT ratios of 0.27-0.49 the incremental yield for this BVOC mix containing significant portions of SQT was $17 \pm 1 \%$. With the onset of the heat stress on day 0 the MT emissions increased more than 20 fold, while the SQT emissions decreased. As can be seen in Fig. 5 (large red triangle), the increased total emissions at day 0 led to more BSOA mass during the heat stress than during the days before. This is only a single observation; however, the data point for day 0 is significantly off the line of the SQT-dominated yield curve. Moreover, the monoterpene-dominated mix at day 0-day 2 (Table 2, red triangles in Fig. 5) gave $8.8 \pm 0.2 \%, R^{2}=0.96$ for the incremental yield. This is lower than that before the heat stress and closer to the expected MT-SOA yields of 4-6\% (Mentel et al., 2009; Lang-Yona et al., 2010).

During the period day 2 to day 5 after applying the heat stress, the plant was held at moderate $T=20^{\circ} \mathrm{C}$ and the MT emissions dropped back to lower amounts, but SQT emissions did not recover. The total BVOC emissions were lower than before the heat stress, and from day 3 on the MT emis-

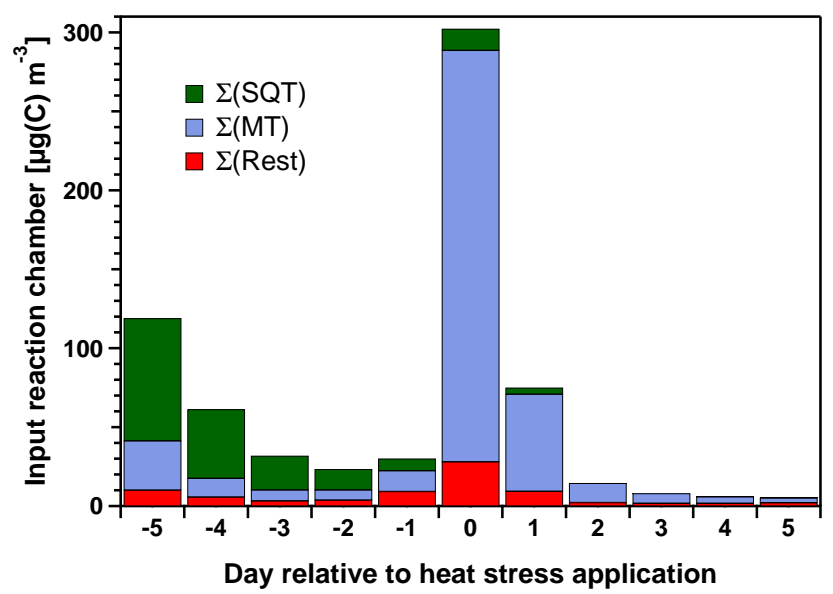

Fig. 4. BVOC concentrations of Experiment \#2 at the inlet of the reaction chamber as determined for the insect-infested spruce before, during and after heat stress application $\left(35^{\circ} \mathrm{C}\right.$ on day 0 and $30^{\circ} \mathrm{C}$ on day 1). Data are the mean of $4 \mathrm{~h}$ before particle formation was induced in the reaction chamber. $\mathrm{SQT}=$ sesquiterpenes, $\mathrm{MT}=$ monoterpenes, Rest $=$ phenolic BVOCs, GLV, and isoprene.

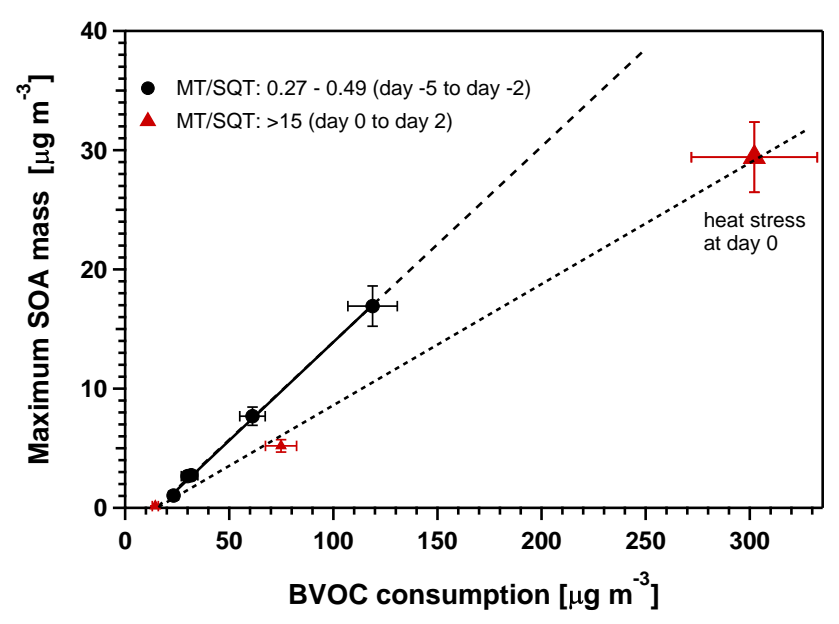

Fig. 5. Maximum BSOA mass produced by $\mathrm{OH}$ oxidation of BVOCs emitted from spruce in Experiment \#2. Circles represent the data points obtained at MT/SQT ratios of $0.27-0.49$ $\left[\mu \mathrm{g} \mathrm{m}^{-3} / \mu \mathrm{g} \mathrm{m}^{-3}\right.$ ] before application of the heat stress (compare Table 2). The solid line shows the result of linear regression analysis giving the yield $17 \pm 1 \%$ (x-intercept $=16 \pm 1 \mu \mathrm{g} \mathrm{m}^{-3}, R^{2}=$ 0.999). The large red triangle shows the data point obtained during heat stress application at day 0 with a MT/SQT ratio of $19\left[\mathrm{\mu g} \mathrm{m}^{-3} / \mathrm{\mu g} \mathrm{m}^{-3}\right]$. The dotted line (slope $0.088 \pm 0.002, R^{2}=$ 0.96 ) is calculated using the data of day 0 to day 2 with MT/SQT $>15$ (compare Table 2). Dashed extrapolation is given for better comparison of the incremental mass yields for both cases. 
sions were so low that formation of particles with $d_{\mathrm{p}}>7 \mathrm{~nm}$ was not observed at all.

\subsection{Experiment \#3: interaction of $\mathrm{C}_{17}-\mathrm{BVOC}$ emissions and GLV emissions during drought stress}

In experiment \#3 with birch, beech, and a spruce infested by Cinara pilicornis, $\mathrm{C}_{17}$-BVOCs dominated the $\mathrm{BVOC}$ mix exiting the plant chamber contributing to about $60 \%$ to the emission of carbon (MT $\sim 30 \%$, SQT $\sim 5 \% \mathrm{GLV} \sim 2 \%$ ). The most abundant $\mathrm{C}_{17}$-compounds were 8 -heptadecene, 6,9-heptadecadiene, and 3,6,9-heptadecatriene. On day 0, when the leaves of the beeches showed strong curling due to the continuing drought, a strong emission pulse of GLV appeared. As shown in Fig. 6, on day 0 the GLV contributed nearly $40 \%$ to the emitted carbon, whereas the contribution of MT dropped from 25 to $4 \%$ (11 to $3 \mathrm{ppbC}$ ). After the strong GLV pulse, the MT remained at a low level $(\sim 4 \%)$. The contribution of GLV was about $10 \%$ for the next days and decreased to roughly $3 \%$ about a week after the strong pulse. Both the contribution of the $\mathrm{C}_{17}$-BVOCs to the emission pattern as well as the absolute emissions of these compounds increased during the period day 1 to day 8 (Fig. 6).

Figure 7 shows the data obtained for maximum BSOA mass during that experiment. With the exception of the strong GLV pulse, we observed a good linear relationship between maximum BSOA volume and BVOC concentrations with an incremental yield of $33 \pm 6 \%$ (black circles in Fig. 7). This yield is even higher than that obtained for the mixtures consisting mainly of SQT $(17 \pm 1 \%), \mathrm{MeSa}(20 \pm 3 \%)$ and SQT $\& \operatorname{MeSA}(22 \pm 2 \%)$. In contrast, the data point obtained at the high GLV contribution to the mixture (green square in Fig. 7, day 0 in Fig. 6) showed a significant deviation from the linear relationship obtained for BVOCs dominated by $\mathrm{C}_{17}$-BVOC emissions. The mix containing the GLV had obviously a much lower potential for BSOA formation than the mix without GLV.

The less efficient particle formation during the GLV emission pulse suggests a counteracting effect of GLV on BSOA yield. Therefore we investigated the impact of GLV emissions on BSOA formation in reference Experiment \#3c with $\alpha$-pinene as constitutive BSOA precursor and (Z)-3-hexenol as surrogate for a GLV. The $\alpha$-pinene concentration was held constant at $43 \pm 4 \mu \mathrm{g} \mathrm{m}^{-3}$, while ( $Z$ )-3-hexenol was added to the chamber in concentrations varying from 0 to $48 \mu \mathrm{g} \mathrm{m}^{-3}$. The amount of BSOA formed from the mixtures of $\alpha$-pinene and $(Z)-3$-hexenol as well as the $\mathrm{OH}$ concentrations in the reaction chamber decreased with increasing $(Z)$-3-hexenol addition (Fig. 8). It is clearly seen that with increasing ( $Z$ )3-hexenol addition and consumption the formation of BSOA mass and the $\mathrm{OH}$ radical concentrations are suppressed (note the logarithmic scale for $\mathrm{OH}$ in Fig. 8). The suppressing impact of (Z)-3-hexenol on particle formation may possibly be similar to that of isoprene (Kiendler-Scharr et al., 2009). The data obtained with $(Z)$-3-hexenol confirmed that the devia-

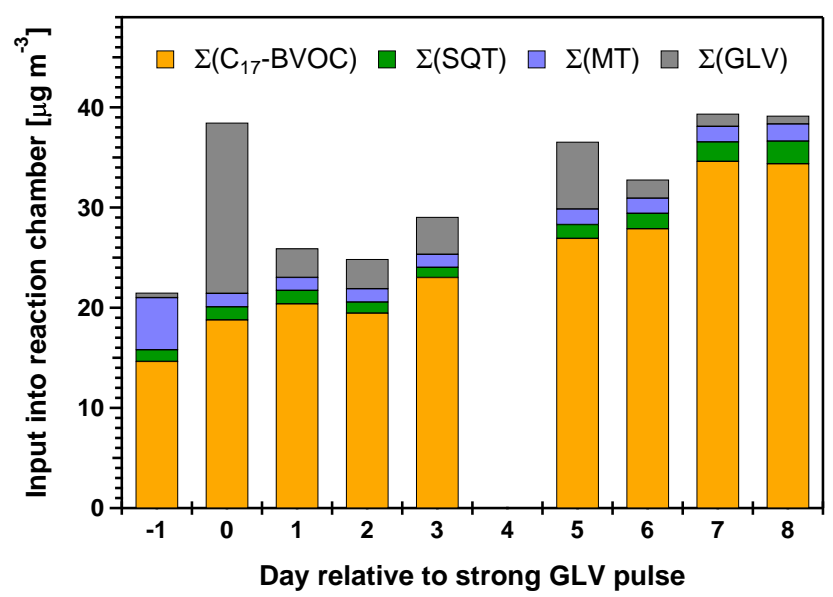

Fig. 6. BVOC pattern in Experiment \#3 measured before, during and after a GLV emission pulse. Day 4 is missing because of an instrument failure.

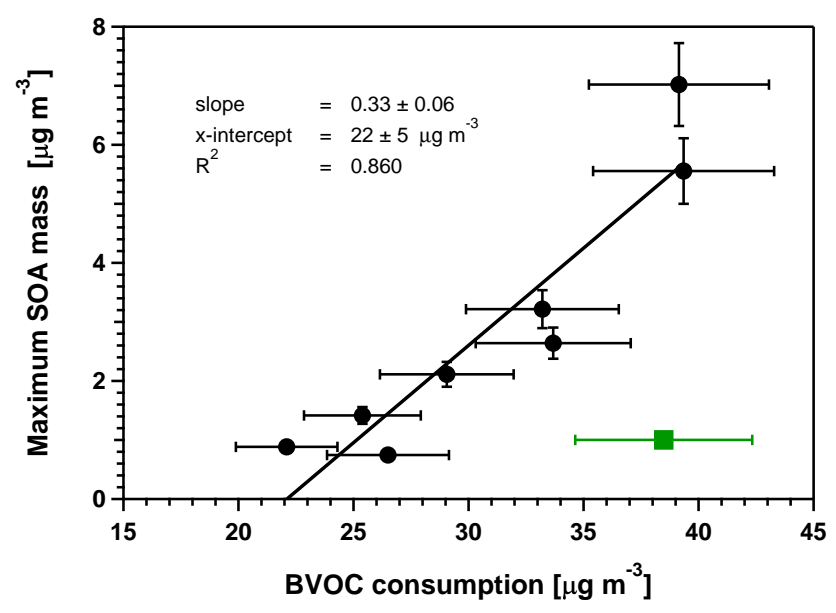

Fig. 7. Maximum BSOA mass versus consumption of $\mathrm{C}_{17}$-BVOCdominated emissions in Experiment \#3. Black circles: data obtained at low contribution of GLV. Green square data point obtained on day 0 at high GLV emissions (see Fig. 6).

tion of the data point at high GLV in Experiment \#3 (green square in Fig. 7) was due to the suppressing effect of GLV.

In all three experiments with plants, the BVOCs were introduced into the reaction chamber together with up to 90 ppb ozone (see the Experimental section). Particle formation $\left(d_{\mathrm{p}}>7 \mathrm{~nm}\right)$ from ozonolysis alone was negligible when BVOC concentrations were below $50 \mu \mathrm{g} \mathrm{m}^{-3}(\sim 100 \mathrm{ppbC})$, even in the presence of up to $36 \% \operatorname{SQT}\left(17 \mu \mathrm{g} \mathrm{m}^{-3}\right)$. In these experiments BVOC concentrations were more than an order of magnitude higher than those typically observed in the planetary boundary layer. Our observation supports the role of $\mathrm{OH}$ for the particle formation process in the atmosphere. 


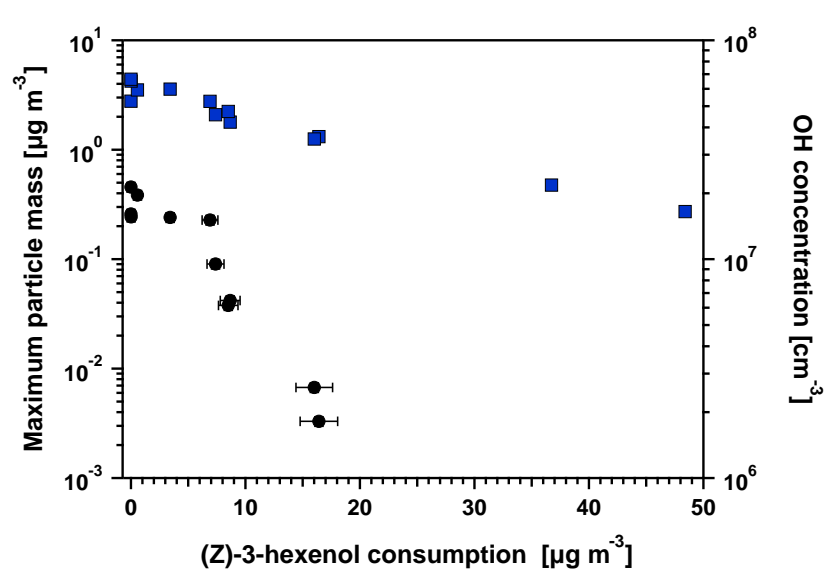

Fig. 8. Maximum particle mass (black circles, left scale) and $\mathrm{OH}$ concentrations (blue squares, right scale) upon addition of up to $48 \mu \mathrm{g} \mathrm{m}^{-3}$ of (Z)-3-hexenol to the reaction chamber filled with $43 \pm 4 \mu \mathrm{g} \mathrm{m}^{-3} \alpha$-pinene. Above $17 \mu \mathrm{g} \mathrm{m}^{-3}$ ( $\left.\sim 6 \mathrm{ppb}\right)$ of $(Z)-3$ hexenol, no particle formation from $\alpha$-pinene oxidation was observed. Note logarithmic scales on both $y$ axes.

\section{Discussion}

\subsection{BSOA formation from constitutive BVOC emissions and SIEs}

In order to assess the impact of SIEs we will refer to previous experiments in the JPAC chamber with unstressed spruce and pine, and $\alpha$-pinene (Mentel et al., 2009). In these cases, MT emissions constituted more than $85 \%$ of the BVOC emissions, and $\mathrm{OH}$-initiated BSOA formation resulted in linear relationships between consumed BVOC mass and observed BSOA mass giving the incremental yields for BSOA formation as listed in Table 4 (Mentel et al., 2009). Because of their low contribution to emissions from the unstressed plants, neither SQT, phenolic BVOCs, nor isoprene had significant impact on the incremental yields in these experiments. The incremental yields for MT-dominated BVOC mixes, including holm oak, were 4 to $6 \%$, independent of the plant species and independent of the detailed MT emission pattern (Mentel et al., 2009; Lang-Yona et al., 2010). Hao et al. (2011) found BSOA mass yields of 3-11\% in experiments with pine and spruce emissions with variable MT pattern, commensurable to our findings, if their higher loads are considered. We derive incremental mass yields of $20 \pm 3 \%$ for MeSa and of $17 \pm 1 \%$ for SQT from Experiments \#1c and \#2, respectively (Table 4). The SQT and MeSa incremental yields are about the same within the errors and we conclude that SQT and $\mathrm{MeSa}$ must have contributed according to their turnover to the BSOA yields of $\approx 20 \%$ in Experiment \#1 (Table 4 and Kiendler-Scharr et al., 2012). Compared to the incremental yields of MT-SOAs, the yields of SQT-SOAs and $\mathrm{MeSa}$-SOAs are about a factor of 4 larger. Therefore we conclude that in biotic stress situations, when plants emit SQT or MeSa, more BSOA mass (and more BSOA particles) can be formed from the same amount of $\mathrm{C}$ emitted as BVOCs.

Under infestation by aphid Cinara pilicornis causing emissions of $\mathrm{C}_{17}$-BVOC, (Experiment \#3) the enhancement of the incremental BSOA yield (33\%) is even larger, about a factor of 6 compared to MT. This is attributed to the $\mathrm{C}_{17^{-}}$ BVOCs. Not much is known with respect to the emissions of the $\mathrm{C}_{17}$-compounds; however, one of the major components, 8-heptadecene, was found by Nazzi et al. (2002) during interactions of the parasitic mite Varroa destructor and plant cells, indicating that the $\mathrm{C}_{17}$-compounds were indeed of biogenic origin. Measurements with the isolated spruce after Experiment \#3 showed that the $\mathrm{C}_{17}$-BVOCs originated indeed from the plant that was infested by the aphid Cinara pilicornis. We did not separate out whether these compounds originated from the plant itself or from the insects or the insects' excrements that were visible as small droplets on needles and branches of the plant. However, independent of the detailed emission mechanism, these compounds originate from the coupled plant-insect system and were therefore treated as a stress-induced BVOC class.

Emissions of MeSa and SQT are not specific for the plant species and stress conditions investigated here. Phenolic BVOCs (with MeSa being predominant) originate from the phenylpropanoid pathway (Colquhoun et al., 2010), and the activity of this pathway is induced in particular by pathogen attack (e.g. Jansen et al., 2011, and references cited therein). Emissions of MeSa and SQT during insect infestation were also reported for Eurasian (Kleist et al., 2012) and for a North American conifer species (Joó et al., 2011). Therefore the importance of our SIE-SOA yields may apply to a wider range of situations and regions despite the limited number of experiments presented here.

\subsection{Impacts of SIEs on BSOA formation and climate}

Since MeSa, SQT, and $\mathrm{C}_{17}$-BVOCs provide a larger incremental yield per emitted carbon than constitutive MT emissions, particles grow to larger sizes. (In addition more aerosol particles were formed in our experiments.) If the biotic stress to plants occurs as a regional phenomenon, the enhanced aerosol size (and number) will contribute on a regional scale to the direct (Pilinis et al., 1995; Chen et al., 2009; Kaufman et al., 2002) and indirect aerosol effects (Albrecht, 1989; Twomey, 1977; Kaufman et al., 2002; Lohmann and Feichter, 2005; Quaas et al., 2009) on climate.

SIE-SOAs will provide extra growth and thus potentially stronger scattering compared to the same turnover of constitutive MT amount. A similar argument holds for the first indirect effect (Twomey effect): to become cloud condensation nuclei, i.e. $\mathrm{CCN}$-active, particles must grow to several tens of $\mathrm{nm}$ or even more. Provided that SIE-SOAs are as good $\mathrm{CCN}$ as MT-SOAs, they will add extra growth and formation of more CCN, which could lead to more and smaller cloud droplets (for a given amount of available water) and thus to 
Table 4. Overview over incremental BSOA mass yields.

\begin{tabular}{lllll}
\hline Name & BVOC source & Action & Major BVOCs & $\begin{array}{l}\text { Incremental } \\
\text { Mass yield }\end{array}$ \\
\hline Exp1 & Stand & Aphid infestation & SQT/MeSa & $22 \pm 2 \%$ \\
Exp1c & Diff. source & & MeSa & $20 \pm 3 \%$ \\
Exp2 & Spruce & Aphid infestation \& heat & SQT & $17 \pm 1 \%$ \\
Exp3 & Stand & Cinara pilicornis infestation \& & C 17 -BVOCs & $33 \pm 6 \%$ \\
& & drought & GLV & \\
Exp3c & Diff. source & & $\alpha$-pinene + & \\
& & & Z-3-hexenol & \\
a & Grey poplar & Ozone pulse & SQT/MeSa & $20 \pm 6 \%$ \\
b & Pine & None & MT 80 $\%$ & $5.3 \pm 0.5 \%$ \\
c & Spruce & MT 90 $\%$ & $4.2 \pm 0.7 \%$ \\
b & Diff. source & & $\alpha$-pinene & $5.2 \pm 0.5 \%$ \\
c & Holm Oak & Heat $25-35^{\circ} \mathrm{C}$ & MT & $6.0 \pm 0.6 \%$ \\
d & Pine /Spruce & None & MT & $3-11 \%$ \\
\hline
\end{tabular}

${ }^{a}$ Kiendler-Scharr et al. (2012), ${ }^{\text {b }}$ Mentel et al. (2009), ${ }^{\mathrm{c}}$ Lang-Yona et al. (2010), and ${ }^{\mathrm{d}}$ Hao et al. (2011).

more reflective clouds. Both direct and first indirect effect eventually exert a cooling effect which counteracts warming, thus constituting an overall negative feedback if the plant stress was favored or caused by heat.

The increase of the cloud droplet number which increases the cloud albedo also prolongates the cloud lifetime by suppression of rain (second indirect effects). If the plant stress that induced GLV emissions is caused or favored by drought periods, suppression of BSOA formation by GLV emissions can decrease the cloud droplet number and increase rain probability. This behavior could also provide a negative feedback.

The discussion above considered only the higher incremental mass yields, thus the potential of SQT and MeSa to form more SOA. The eventual effect does not only depend on the incremental yield but also on the emitted amounts of BVOCs and their turnover in the atmosphere. In a situation of long periods with increased SIEs as depicted in Figs. 1 and 6, the situation is straightforward and will lead to aerosol effects as sketched above. However, if stress causes plant damage as shown in Experiment \#2 (Fig. 4), the BSOA production may die out to zero after a short pulse.

The situation becomes more complex if one considers the GLV that were triggered by drought stress. Although GLV themselves have some limited mass yield of $3 \%$ (for $(Z)-3$ hexenol, Hamilton et al., 2009), they can hinder BSOA formation from constitutive emissions such as $\alpha$-pinene (Experiment \#3c) or diminish the BSOA potential even of the very effective SIEs of $\mathrm{C}_{17}$-BVOCs (green data point in Fig. 7). This effect of GLV goes along with a drop in OH radical concentration (Fig. 8), in contrast to the effect of MeSa (Fig. 3). The GLV effect shows similarity to the suppressing effect of isoprene (Kiendler-Scharr et al., 2009, 2012), where the reactive isoprene with a limited BSOA mass yield of a few percent prevents nucleation and BSOA formation from con- stitutive MT emission and SIEs, respectively. While climate warming could enhance the isoprene-to-MT ratio steadily, the GLV effect would become active episodically whenever plants are damaged in cases such as drought stress. This may lead to a positive feedback, namely, drought $\rightarrow$ GLV $\rightarrow$ less $\mathrm{OH} \rightarrow$ less BSOA $\rightarrow$ increasing heat $\rightarrow$ extended drought.

\subsection{Examples for possible feedback effects via SIE-SOAs}

Although we quantified BSOA formation potentials for various SIEs, the difficulty to quantify stressors and their impacts impedes quantitative upscaling of our results, as the amounts of current and future SIEs remain unknown. A major uncertainty herein is the future evolution of biotic stressors like pathogen and insect attacks. The effect of climate change on pathogens and herbivorous insects depends on the detailed conditions of the ecosystems. However, there is evidence that biotic stress will increase together with heat waves and droughts (e.g. Ayres and Lombardero, 2000; Arneth and Niinemets, 2010; Bentz et al., 2010; Hicke et al., 2012; Sturrock et al., 2011). Indeed, plant responses to biotic stresses are highly complex, and the biotic stressors applied in this study may represent only a limited set of biotic stress in general, presumably even for insect attacks. Nevertheless we intend to initialize a discussion about SIEs and SIE-SOAs in current and future climate. Important aspects herein are feedbacks and couplings between vegetation, atmosphere, and climate.

Previous studies provided some basic knowledge about impacts of stress on BVOC emissions. The number of biosynthetic pathways wherein SIEs are synthesized is limited, and SIE production proceeds via the induction of activities within these biosynthetic pathways. Therefore classes of SIEs as GLV, phenolic BVOCs, mono- or sesquiterpenes 
Table 5. BVOC emissions used for estimating impacts of stress-induced emissions on BSOA formation. Type: Const = constitutive emissions, SIEs = stress-induced emissions. The BSOA column gives the effect of emissions on BSOA assuming increase in emission strengths of the respective BVOC group. The arrows in columns biotic, heat and drought indicate expected trends for the emissions of the respective BVOC group in case of biotic, heat, and drought stress, respectively.

\begin{tabular}{llcccc}
\hline BVOC group & Type & BSOA & Aphid infestation & Heat & Drought \\
\hline MT emissions from pools & Const. & $\uparrow$ & $\uparrow^{\mathrm{a}}$ & $\uparrow^{\mathrm{g}}$ & $* j$ \\
MT de novo emissions & Const. & $\uparrow$ & $\uparrow^{\mathrm{b}, \mathrm{c}}$ & $\downarrow^{\mathrm{g}}$ & $\downarrow^{\mathrm{j}, \mathrm{l}}$ \\
Isoprene & Const. & $\downarrow$ & $\uparrow^{\mathrm{d}}$ & $\downarrow^{\mathrm{h}, \mathrm{i}}$ & $\downarrow^{1, \mathrm{~m}}$ \\
SQT/de novo & SIEs & $\uparrow$ & $\uparrow^{\mathrm{e}, \mathrm{f}, \mathrm{g}}$ & $\downarrow^{\mathrm{g}}$ & $\downarrow^{\mathrm{n}, \mathrm{o}}$ \\
phenolic BVOCs & SIEs & $\uparrow$ & $\uparrow^{\mathrm{f}, \mathrm{g}}$ & $\downarrow^{\mathrm{g}}$ & - \\
GLV & SIEs & $\downarrow$ & $\uparrow$ & $\uparrow^{\mathrm{g}}$ & $\uparrow^{\mathrm{k}}$ \\
C $_{17-\mathrm{BVOCs}}$ & SIEs & $\uparrow$ & $\uparrow$ & - & - \\
\hline
\end{tabular}

-: not described in literature, $*$ : low direct stress impacts,

${ }^{a}$ Niinemets et al. (2010), ${ }^{b}$ Maes and Debergh (2003), ${ }^{c}$ Arimura et al. (2004), ${ }^{d}$ Arneth and Niinemets (2010),

${ }^{\mathrm{e}}$ Boland et al. (1995), ${ }^{\mathrm{f}}$ Joó et al. (2011), ${ }^{\mathrm{g}}$ Kleist et al. (2012), ${ }^{\mathrm{h}}$ Guenther et al. (1993), ${ }^{\mathrm{i}}$ Rasulov et al. (2010),

j Blanch et al. (2007), ${ }^{\mathrm{k}}$ Šimpraga et al. (2011), ${ }^{1}$ Laothawornkitkul et al. (2009), ${ }^{\mathrm{m}}$ Brilli et al. (2007), ${ }^{\mathrm{n}}$ Hansen

and Seufert (1999), ${ }^{\circ}$ Ormeño et al. (2007).

in different proportions are emitted in response to the biotic stress. As we found that classes of BVOCs have similar BSOA yields (Table 4), the variability of BSOA formation potential compared to the variability of emissions is strongly diminished.

Based on this knowledge we will discuss a case scenario (Table 5) wherein we only consider the aerosol effects of constitutive MT-SOAs and SIE-SOAs based on the formation potentials in Table 4. In Table 5 we sketch expected effects of BVOC emissions on BSOA formation based on the results presented here. Furthermore possible responses of constitutive emissions and SIEs to aphid infestation and to heat and drought are outlined. In Table 5 we took also into account the basic emission mechanisms as BVOC emissions may either be produced de novo or arise from storage in plant organs and impacts of stress vary with the emission mechanisms. For example, heat or drought can strongly suppress overall biosynthetic activity. Coherently, de novo MT emissions will tend to decrease. However, under heat stress MT emissions from plant internal pools can still increase on timescales of days to weeks (e.g. Kleist et al., 2012).

The base cases are constitutive MT emissions. Incremental yields of MT are independent of the detailed MT mix, and the amount of produced particle mass predominantly depends on the amount of emitted MT (Mentel et al., 2009; Lang-Yona et al., 2010; Hao et al., 2011). The increased BSOA mass due to increasing MT emissions is indicated by the upward-pointing arrow in the "BSOA" column in Table 5. The prediction of future BVOC emissions is uncertain; however, according to e.g. Lathière et al. (2005) higher mean temperatures as well as expansion of vegetation zones will cause higher overall MT emissions, resulting in higher BSOA mass (Tsigaridis and Kanakidou, 2007). Hence, under negligible stress, the consequence of increased MT emissions will be a negative climatic feedback, as already suggested by Kulmala et al. (2004) and corroborated by Spracklen et al. (2008). However, already the presence of more than $10 \%$ of isoprene in a given constitutive mix will suppress particle formation (Kiendler-Scharr et al., 2009). As indicated by downward-pointing arrow in the "BSOA" column in Table 5, increasing isoprene emissions will thus weaken the negative feedback of MT-SOAs.

SIEs are not abundant when the plants do not suffer from that stress. Therefore biotic stresses increase the emission of BVOCs, which in the case of MeSa, SQT, and $\mathrm{C}_{17}$-BVOCs have in addition a higher SOA formation potential than constitutive emissions (Table 4). Emissions of SQT, phenolic BVOCs, or $\mathrm{C}_{17}$-BVOCs may appear only episodically and not permanently. Nevertheless, these emissions can last for weeks, and with high BSOA formation potentials of $20 \%$ or $30 \%$ they may have a substantial impact. Thus, biotic stress - more precisely, aphid infestation - will likely enhance SIEs and, as was shown in this study, will lead to increased BSOA formation (upward arrows Table 5) unless the stressor induces strong GLV emissions. In cases of strong GLV emissions the yields of BSOA formation will be suppressed as indicated by the downward arrow in Table 5. It is therefore likely that biotic stress will always lead to a negative feedback as long as the stress is not killing the host and GLV emissions remain low.

In an example we will now apply the scenario in Table 5 in order to depict that possible couplings between stress to plants, BSOA formation, and changing climate are very complicated. For simplicity the impacts of future stress on particle formation are assessed for the isolated ecosystem and impacts on net photosynthesis and transpiration are not considered. We also neglect complications by possible anthropogenic enhancement of biogenic SOA production (Kanakidou et al., 2000; de Gouw et al., 2005; Tsigaridis and Kanakidou, 2007; Weber et al., 2007; de Gouw and Jiminez, 2009; Clarton et al., 2010; Spracklen et al., 2011). We further do not take into account that future climate conditions will likely alter the physico-chemical processes leading to 


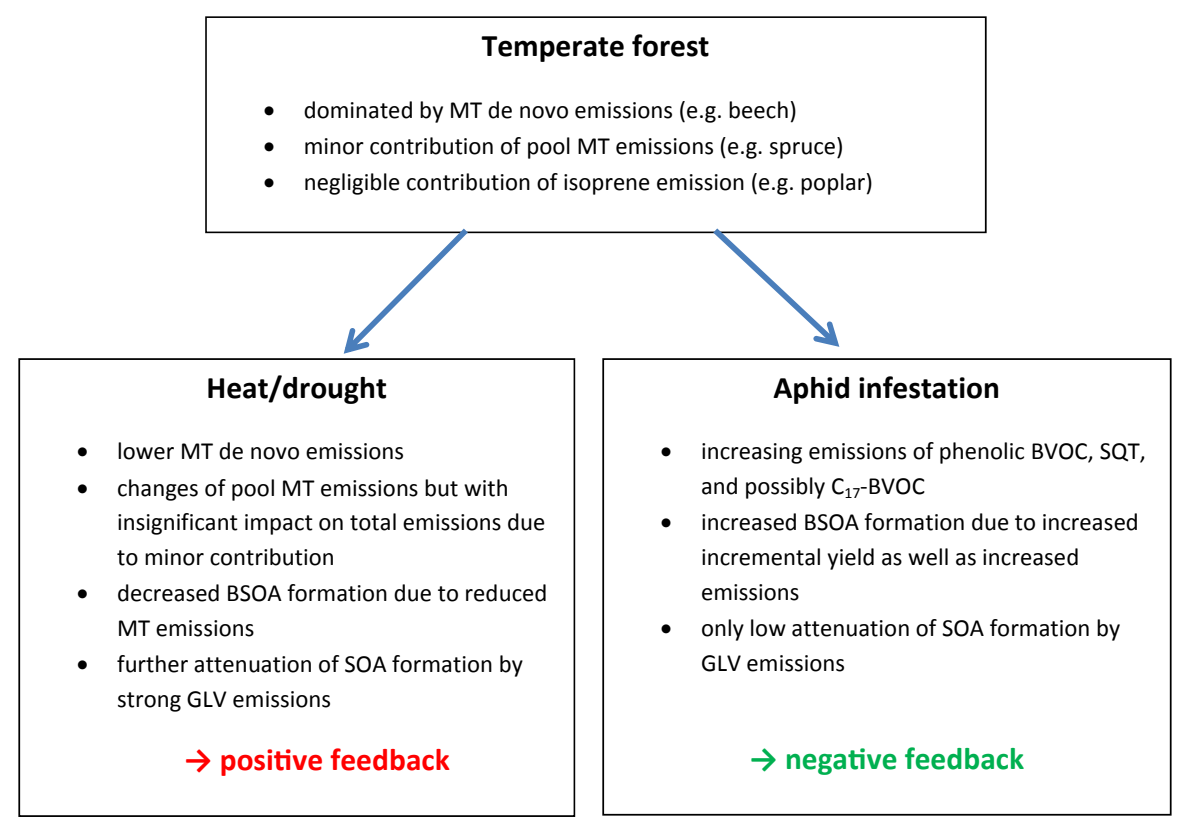

Fig. 9. Examples of estimated climate feedbacks of stress to temperate forests. Under negative feedback we understand that enhanced BSOA formation and related direct and indirect effects counteract heat and drought. In case of positive feedback the reduced BSOA formation enhances effects of heat and drought. For biotic stress we refer to the case of heat and drought increasing the chance of pathogen and herbivore attack.

particle formation in the atmosphere as well as atmospheric boundary layer conditions such as $\mathrm{OH}$ levels and $\mathrm{NO}_{\mathrm{x}}$ concentrations. Each of those omissions will modify the simplified scenario in Table 5 in one way or the other when taken into account, but will probably not reverse the qualitative trends.

For estimation of the sign of possible feedbacks we refer to the relation of increasing BSOA production, particle size, and cooling aerosol effects as described in Sect. 4.2. Therefore, if less particulate mass is produced from the BVOC mix either by reduced amounts of emissions or by suppression by isoprene and GLV, we expect a positive feedback. If more BSOA mass is produced from increased emissions of MT, we expect a negative feedback.

Based on these considerations we show two possible feedback schemes for the example of a temperate forest suffering either from heat/drought or from an aphid infestation (Fig. 9). Under heat and drought stress the BVOC emissions from the forest will decrease. BSOA formation will be also decrease if de novo emissions of MT dominate. Reduced BSOA formation will result in a positive climatic feedback. In contrast, aphid infestation has only negligible impacts on constitutive MT emissions but can induce strong emissions of phenolic BVOCs, SQT or $\mathrm{C}_{17}$-BVOCs. As long as aphid infestations do not induce strong GLV emissions, higher BSOA yields are expected due to higher total emission strength and the higher incremental yield of the SIEs that make the new BVOC mix.
Such a scenario would lead to a negative climate feedback (Topping et al., 2013; Paasonen et al., 2013).

Compensating effects may operate in the same forest type with a certain mixture of BVOC emitters (trees). The situation will become more complex when more stresses act together. If future climate favors aphid infestation, this will cause a negative feedback as sketched in Fig. 9. Severe heat stress can change this scenario. Upon heat stress, constitutive de novo MT emissions and SIEs will be suppressed (Kleist et al., 2012) and, depending on the degree of this effect, the negative feedback may switch to a positive feedback.

In an environment with diverse ecosystems and a variety of biotic and abiotic stresses, scenarios are even more complex, making even qualitative extrapolations of our findings difficult. However, if the class composition is known, it would be possible to calculate the effect of BSOA based on our findings. Note that other factors, such as stress impacts on net photosynthesis and transpiration as well as changing physico-chemical processes in the atmosphere, should be considered in addition.

Despite the complexity, impacts of biotic stresses on ecosystems and impacts of climate change on top are obviously important and should be considered. As an example, the expansion of tree damage by bark beetles in the Rocky Mountains and its front range has been linked to climatic change and the associated temperature changes (Bentz et al., 2010; Berg et al., 2013). Such extreme events should have impacts on the pattern and amount of the BVOCs emitted 
from the ecosystem, causing alterations of BSOA formation on a regional scale. Ongoing climate change with probably extreme events may exert significant stresses onto the ecosystem. We therefore conclude that also with respect to BVOC emissions the ecosystem response to different stress must be considered when developing scenarios for future climate change. Taking into account only the negative feedback by higher BVOC emissions and BSOA formation due to mean temperature increase may fall too short considering the complexity of the system.

\section{Conclusions}

We determined the BSOA formation potential of stressinduced emissions (SIEs) from common trees of temperate and Boreal forests (pine, spruce, birch, and beech). BSOA mass yields were larger than those due to constitutive monoterpene (MT) emissions: $17 \pm 1 \%$ for sesquiterpenes (SQT), $20 \pm 3 \%$ for methlyl salicylate (MeSa), and $33 \pm 6 \%$ for $\mathrm{C}_{17}$-BVOCs. In contrast to these SIE classes, green leaf volatiles (GLV) emitted due to stress have the potential to decrease BSOA mass and number. Increased GLV emissions support positive feedback in case GLV emissions are related to heat but exert a potential negative feedback when related to drought. Our results clearly indicate that different stress conditions can affect biogenic BSOA production: stress-induced changes of BVOC emission patterns and strength strongly impact BSOA formation, causing increased (SQT, MeSa, $\mathrm{C}_{17}$-BVOCs) or decreased (GLV) BSOA formation.

Our study and consequent considerations strongly suggest the importance of SIEs for possible feedbacks between climate and vegetation via BSOA formation. Biotic stress such as aphid infestation supports negative feedback, and this may be effective already today. But heat and drought can turn the negative feedback proposed by Kulmala et al. (2004) and Goldstein et al. (2009) into a positive feedback, e.g. in forests dominated by de novo emitters. Since it is likely that climate change will affect SIEs from vegetation, SIEs and their BSOA formation potential have to be considered in future climate scenarios.

Acknowledgements. The authors acknowledge financial support by the integrated EU projects EUCAARI (contract no. 036833-2) and PEGASOS (contract no. 265307). Y. Rudich acknowledges support from the US-Israel bi-national science foundation (BSF) contract number 2008/146 and support by the Helen and Martin Kimmel Award for Innovative Investigation.

The service charges for this open access publication have been covered by a Research Centre of the Helmholtz Association.

Edited by: E. Nemitz

\section{References}

Albrecht, B. A.: Aerosols, cloud microphysics, and fractional cloudiness, Science, 245, 1227-1230, doi:10.1126/science.245.4923.1227, 1989.

Arimura, G., Huber, D. P. W., and Bohlmann, J.: Forest tent caterpillars (malacosoma disstria) induce local and systemic diurnal emissions of terpenoid volatiles in hybrid poplar (populus trichocarpa $x$ deltoides): cDNA cloning, functional characterization, and patterns of gene expression of (-)-germacrene $d$ synthase, PtdTPS1, Plant J., 37, 603-616, doi:10.1111/j.1365313X.2003.01987.x, 2004.

Arneth, A. and Niinemets, Ü.: Induced BVOCS: How to bug our models?, Trends Plant Sci., 15, 118-125, 2010.

Arneth, A., Harrison, S. P., Zaehle, S., Tsigaridis, K., Menon, S., Bartlein, P. J., Feichter, J., Korhola, A., Kulmala, M., O’Donnell, D., Schurgers, G., Sorvari, S., and Vesala, T.: Terrestrial biogeochemical feedbacks in the climate system, Nature Geosci., 3, 525-532, doi:10.1038/ngeo905, 2010.

Ayres, M. P. and Lombardero, M. J.: Assessing the consequences of global change for forest disturbance from herbivores and pathogens, Sci. Total Environ., 262, 263-286, doi:10.1016/s0048-9697(00)00528-3, 2000.

Bentz, B. J., Regniere, J., Fettig, C. J., Hansen, E. M., Hayes, J. L., Hicke, J. A., Kelsey, R. G., Negron, J. F., and Seybold, S. J.: Climate change and bark beetles of the Western United States and Canada: Direct and indirect effects, Bioscience, 60, 602613, doi:10.1525/bio.2010.60.8.6, 2010.

Berg, A. R., Heald, C. L., Huff Hartz, K. E., Hallar, A. G., Meddens, A. J. H., Hicke, J. A., Lamarque, J.-F., and Tilmes, S.: The impact of bark beetle infestations on monoterpene emissions and secondary organic aerosol formation in western North America, Atmos. Chem. Phys., 13, 3149-3161, doi:10.5194/acp-13-31492013, 2013.

Blanch, J. S., Peñuelas, J., and Llusià, J.: Sensitivity of terpene emissions to drought and fertilization in terpene-storing pinus halepensis and non-storing quercus ilex, Physiologia Plantarum, 131, 211-225, doi:10.1111/j.1399-3054.2007.00944.x, 2007.

Brilli, F., Barta, C., Fortunati, A., Lerdau, M., Loreto, F., and Centritto, M.: Response of isoprene emission and carbon metabolism to drought in white poplar (populus alba) saplings, New Phytol., 175, 244-254, doi:10.1111/j.1469-8137.2007.02094.x, 2007.

Boland, W., Hopke, J., Donath, J., Nuske, J., and Bublitz, F.: Jasmonic acid and coronatin induce odor production in plants, Angew. Chemie-Internat. Edition, 34, 1600-1602, doi:10.1002/anie.199516001, 1995.

Carslaw, K. S., Boucher, O., Spracklen, D. V., Mann, G. W., Rae, J. G. L., Woodward, S., and Kulmala, M.: A review of natural aerosol interactions and feedbacks within the Earth system, Atmos. Chem. Phys., 10, 1701-1737, doi:10.5194/acp-10-17012010, 2010.

Chen, I. C., Hill, J. K., Ohlemuller, R., Roy, D. B., and Thomas, C. D.: Rapid range shifts of species associated with high levels of climate warming, Science, 333, 1024-1026, doi:10.1126/science.1206432, 2011.

Chen, Y., Li, Q. B., Kahn, R. A., Randerson, J. T., and Diner, D. J.: Quantifying aerosol direct radiative effect with multiangle imaging spectroradiometer observations: Top-of-atmosphere albedo change by aerosols based on land surface types, J. Geophys. Res., 114, D02109, doi:10.1029/2008jd010754, 2009. 
Clarton, A. G., Pinder, R. W., Bhave, P. V., and Pouliot, G. A.: To what extent can biogenic SOA be controlled?, Environ. Sci. Technol., 44, 3376-3380, 2010.

Colquhoun, T. A., Schimmel, B. C. J., Kim, J. Y., Reinhardt, D., Cline, K., and Clark, D. G.: A petunia chorismate mutase specialized for the production of floral volatiles, Plant J., 61, 145-155, doi:10.1111/j.1365-313X.2009.04042.x, 2010.

Croft, K. P. C., Juttner, F., and Slusarenko, A. J.: Volatile products of the lipoxygenase pathway evolved from phaseolus vulgaris (L.) leaves inoculated with pseudomonas syringae pv phaseolicola, Plant Physiol., 101, 13-24, 1993.

Dal Maso, M., Hari, P., and Kulmala, M.: Spring recovery of photosynthesis and atmospheric particle formation, Boreal Environ. Res., 14, 711-721, 2009.

de Gouw, J. A. and Jimenez, J. L.: Organic Aerosols in the Earth's Atmosphere, Environ. Sci. Technol., 43, 7614-7618, doi:10.1021/es9006004, 2009.

de Gouw, J. A., Middlebrook, A. M., Warneke, C., Goldan, P. D., Kuster, W. C., Roberts, J. M., Fehsenfeld, F. C., Worsnop, D. R., Canagaratna, M. R., Pszenny, A. A. P., Keene, W. C., Marchewka, M., Bertman, S. B., and Bates, T. S.: Budget of organic carbon in a polluted atmosphere: Results from the New England Air Quality Study in 2002, J. Geophys. Res.-Atmos., 110, D16305, doi:10.1029/2004jd005623, 2005.

Goldstein, A. H., Koven, C. D., Heald, C. L., and Fung, I. Y.: Biogenic carbon and anthropogenic pollutants combine to form a cooling haze over the southeastern united states, P. Natl. Acad. Sci., 106, 8835-8840, doi:10.1073/pnas.0904128106, 2009.

Gouinguene, S. P. and Turlings, T. C. J.: The effects of abiotic factors on induced volatile emissions in corn plants, Plant Physiol., 129, 1296-1307, doi:10.1104/pp.001941, 2002.

Guenther, A., Hewitt, C. N., Erickson, D., Fall, R., Geron, C., Graedel, T., Harley, P., Klinger, L., Lerdau, M., McKay, W. A., Pierce, T., Scholes, B., Steinbrecher, R., Tallamraju, R., Taylor, J., and Zimmerman, P.: A global model of natural volatile organic compound emissions, J. Geophys. Res., 100, 8873-8892, 1995.

Guenther, A. B., Zimmerman, P. R., Harley, P. C., Monson, R. K., and Fall, R.: Isoprene and monoterpene emission rate variability - model evaluations and sensitivity analyses, J. Geophys. Res., 98, 12609-12617, doi:10.1029/93jd00527, 1993.

Guenther, A. B., Jiang, X., Heald, C. L., Sakulyanontvittaya, T., Duhl, T., Emmons, L. K., and Wang, X.: The Model of Emissions of Gases and Aerosols from Nature version 2.1 (MEGAN2.1): an extended and updated framework for modeling biogenic emissions, Geosci. Model Dev., 5, 1471-1492, doi:10.5194/gmd-51471-2012, 2012.

Hamilton, J. F., Lewis, A. C., Carey, T. J., Wenger, J. C., Borrás i Garcia, E., and Muñoz, A.: Reactive oxidation products promote secondary organic aerosol formation from green leaf volatiles, Atmos. Chem. Phys., 9, 3815-3823, doi:10.5194/acp-9-38152009, 2009.

Hansen, U. and Seufert, G.: Terpenoid emission from Citrus sinensis (L.) OSBECK under drought stress, Phys. Chem. Earth B, 24, 681-687, doi:10.1016/s1464-1909(99)00065-9, 1999.

Hao, L. Q., Romakkaniemi, S., Yli-Pirilä, P., Joutsensaari, J., Kortelainen, A., Kroll, J. H., Miettinen, P., Vaattovaara, P., Tiitta, P., Jaatinen, A., Kajos, M. K., Holopainen, J. K., Heijari, J., Rinne, J., Kulmala, M., Worsnop, D. R., Smith, J. N., and Laaksonen, A.: Mass yields of secondary organic aerosols from the oxida- tion of $\alpha$-pinene and real plant emissions, Atmos. Chem. Phys., 11, 1367-1378, doi:10.5194/acp-11-1367-2011, 2011.

Heald, C. L., Henze, D. K., Horowitz, L. W., Feddema, J., Lamarque, J. F., Guenther, A., Hess, P. G., Vitt, F., Seinfeld, J. H., Goldstein, A. H., and Fung, I.: Predicted change in global secondary organic aerosol concentrations in response to future climate, emissions, and land use change, J. Geophys. Res., 113, D05211, doi:10.1029/2007jd009092, 2008.

Heiden, A. C., Hoffmann, T., Kahl, J., Kley, D., Klockow, D., Langebartels, C., Mehlhorn, H., Sandermann, H., Schraudner, M., Schuh, G., and Wildt, J.: Emission of volatile organic compounds from ozone-exposed plants, Ecol. Appl., 9, 1160-1167, 1999.

Heiden, A. C., Kobel, K., Langebartels, C., Schuh-Thomas, G., and Wildt, J.: Emissions of oxygenated volatile organic compounds from plants - part I: Emissions from lipoxygenase activity, J. Atmos. Chem., 45, 143-172, 2003.

Hicke, J. A., Allen, C. D., Desai, A. R., Dietze, M. C., Hall, R. J., Hogg, E. H., Kashian, D. M., Moore, D., Raffa, K. F., Sturrock, R. N., and Vogelmann, J.: Effects of biotic disturbances on forest carbon cycling in the United States and Canada, Glob. Change Biol., 18, 7-34, doi:10.1111/j.1365-2486.2011.02543.x, 2012.

Hopke, J., Donath, J., Blechert, S., and Boland, W.: Herbivoreinduced volatiles - the emission of acyclic homoterpenes from leaves of Phaseolus lunatus and Zea mays can be triggered by a $\beta$-glucosidase and jasmonic acid, FEBS Letters, 352, 146-150, doi:10.1016/0014-5793(94)00948-1, 1994.

Jansen, R. M. C., Wildt, J., Kappers, I. F., Bouwmeester, H. J., Hofstee, J. W., and van Henten, E. J.: Detection of diseased plants by analysis of volatile organic compound emission. Annu. Rev. Phytopathol., 49, 157-174, 2011.

Joó, E., Dewulf, J., Amelynck, C., Schoon, N., Pokorska, O., Šimpraga, M., Steppe, K., Aubinet, M., and Van Langenhove, H.: Constitutive versus heat and biotic stress induced BVOC emissions in Pseudotsuga menziesii, Atmos. Environ., 45, 36553662, doi:10.1016/j.atmosenv.2011.04.048, 2011.

Joutsensaari, J., Loivamäki, M., Vuorinen, T., Miettinen, P., Nerg, A.-M., Holopainen, J. K., and Laaksonen, A.: Nanoparticle formation by ozonolysis of inducible plant volatiles, Atmos. Chem. Phys., 5, 1489-1495, doi:10.5194/acp-5-1489-2005, 2005.

Kanakidou, M., Tsigaridis, K., Dentener, F. J., and Crutzen, P. J.: Human-activity-enhanced formation of organic aerosols by biogenic hydrocarbon oxidation, J. Geophys. Res., 105, 9243-9254, 2000.

Kaufman, Y. J., Tanre, D., and Boucher, O.: A satellite view of aerosols in the climate system, Nature, 419, 215-223, doi:10.1038/nature01091, 2002.

Kerminen, V. M., Lihavainen, H., Komppula, M., Viisanen, Y., and Kulmala, M.: Direct observational evidence linking atmospheric aerosol formation and cloud droplet activation, Geophys. Res. Lett., 32, L14803, doi:14810.11029/12005GL023130, 2005.

Kesselmeier, J. and Staudt, M.: Biogenic volatile organic compounds (VOC): An overview on emission, physiology and ecology, J. Atmos. Chem., 33, 23-88, doi:10.1023/a:1006127516791, 1999.

Kiendler-Scharr, A., Wildt, J., Dal Maso, M., Hohaus, T., Kleist, E., Mentel, T. F., Tillmann, R., Uerlings, R., Schurr, U., and Wahner, A.: New particle formation in forests inhibited by isoprene emissions, Nature, 461, 381-384, doi:10.1038/nature08292, 2009. 
Kiendler-Scharr, A., Andres, S., Bachner, M., Behnke, K., Broch, S., Hofzumahaus, A., Holland, F., Kleist, E., Mentel, T. F., Rubach, F., Springer, M., Steitz, B., Tillmann, R., Wahner, A., Schnitzler, J.-P., and Wildt, J.: Isoprene in poplar emissions: effects on new particle formation and $\mathrm{OH}$ concentrations, Atmos. Chem. Phys., 12, 1021-1030, doi:10.5194/acp-12-1021-2012, 2012.

Kleist, E., Mentel, T. F., Andres, S., Bohne, A., Folkers, A., Kiendler-Scharr, A., Rudich, Y., Springer, M., Tillmann, R., and Wildt, J.: Irreversible impacts of heat on the emissions of monoterpenes, sesquiterpenes, phenolic BVOC and green leaf volatiles from several tree species, Biogeosciences, 9, 51115123, doi:10.5194/bg-9-5111-2012, 2012.

Kulmala, M., Suni, T., Lehtinen, K. E. J., Dal Maso, M., Boy, M., Reissell, A., Rannik, Ü., Aalto, P., Keronen, P., Hakola, H., Bäck, J., Hoffmann, T., Vesala, T., and Hari, P.: A new feedback mechanism linking forests, aerosols, and climate, Atmos. Chem. Phys., 4, 557-562, doi:10.5194/acp-4-557-2004, 2004.

Lang-Yona, N., Rudich, Y., Mentel, Th. F., Bohne, A., Buchholz, A., Kiendler-Scharr, A., Kleist, E., Spindler, C., Tillmann, R., and Wildt, J.: The chemical and microphysical properties of secondary organic aerosols from Holm Oak emissions, Atmos. Chem. Phys., 10, 7253-7265, doi:10.5194/acp-10-7253-2010, 2010.

Laothawornkitkul, J., Taylor, J. E., Paul, N. D., and Hewitt, C. N.: Biogenic volatile organic compounds in the earth system, New Phytol., 183, 27-51, doi:10.1111/j.1469-8137.2009.02859.x, 2009.

Lathière, J., Hauglustaine, D. A., De Noblet-Ducoudré, N., Krinner, G., and Folberth, G. A.: Past and future changes in biogenic volatile organic compound emissions simulated with a global dynamic vegetation model, Geophys. Res. Lett., 32, L20818, doi:10.1029/2005GL024164, 2005.

Lohmann, U. and Feichter, J.: Global indirect aerosol effects: a review, Atmos. Chem. Phys., 5, 715-737, doi:10.5194/acp-5-7152005, 2005.

Loreto, F. and Schnitzler, J. P.: Abiotic stresses and induced BVOCs, Trends Plant Sci., 15, 154-166, doi:10.1016/j.tplants.2009.12.006, 2010.

Maes, K. and Debergh, P. C.: Volatiles emitted from in vitro grown tomato shoots during abiotic and biotic stress, Plant Cell Tissue and Organ Culture, 75, 73-78, doi:10.1023/a:1024650006740, 2003.

Mentel, Th. F., Wildt, J., Kiendler-Scharr, A., Kleist, E., Tillmann, R., Dal Maso, M., Fisseha, R., Hohaus, Th., Spahn, H., Uerlings, R., Wegener, R., Griffiths, P. T., Dinar, E., Rudich, Y., and Wahner, A.: Photochemical production of aerosols from real plant emissions, Atmos. Chem. Phys., 9, 4387-4406, doi:10.5194/acp9-4387-2009, 2009.

Nazzi, F., Milani, N., and Della Vedova, G.: (Z)-8-heptadecene from infested cells reduces the reproduction of varroa destructor under laboratory conditions, J. Chem. Ecol., 28, 2181-2190, doi:10.1023/a:1021041130593, 2002.

Niinemets, Ü., Arneth, A., Kuhn, U., Monson, R. K., Peñuelas, J., and Staudt, M.: The emission factor of volatile isoprenoids: stress, acclimation, and developmental responses, Biogeosciences, 7, 2203-2223, doi:10.5194/bg-7-2203-2010, 2010.

Ormeño, E., Mévy, J. P., Vila, B., Bousquet-Mélou, A., Greff, S., Bonin, G., and Fernandez, C.: Water deficit stress in- duces different monoterpene and sesquiterpene emission changes in mediterranean species. Relationship between terpene emissions and plant water potential, Chemosphere, 67, 276-284, doi:10.1016/j.chemosphere.2006.10.029, 2007.

Paasonen, P., Asmi, A., Petäjä, T., Kajos, M. K., Aijälä, M., Junninen, H., Holst, T., Abbatt, J. P. D., Arneth, A., Birmili, W., van der Gon, H. D., Hamed, A., Hoffer, A., Laakso, L., Laaksonen, A., Richard Leaitch, W., Plass-Dülmer, C., Pryor, S. C., Räisäne,n P., Swietlicki, E., Wiedensohler, A., Worsnop, D. R., Kerminen, V.-M., and Kulmala, M.: Warming-induced increase in aerosol number concentration likely to moderate climate change, Nature Geosci., 6, 438-442, 2013.

Peñuelas, J. and Staudt, M.: BVOCs and global change, Trends Plant Sci., 15, 133-144, doi:10.1016/j.tplants.2009.12.005, 2010.

Pilinis, C., Pandis, S. N., and Seinfeld, J. H.: Sensitivity of direct climate forcing by atmospheric aerosols to aerosolsize and composition, J. Geophys. Res., 100, 18739-18754, doi:10.1029/95jd02119, 1995.

Quaas, J., Ming, Y., Menon, S., Takemura, T., Wang, M., Penner, J. E., Gettelman, A., Lohmann, U., Bellouin, N., Boucher, O., Sayer, A. M., Thomas, G. E., McComiskey, A., Feingold, G., Hoose, C., Kristjánsson, J. E., Liu, X., Balkanski, Y., Donner, L. J., Ginoux, P. A., Stier, P., Grandey, B., Feichter, J., Sednev, I., Bauer, S. E., Koch, D., Grainger, R. G., Kirkevåg, A., Iversen, T., Seland, Ø., Easter, R., Ghan, S. J., Rasch, P. J., Morrison, H., Lamarque, J.-F., Iacono, M. J., Kinne, S., and Schulz, M.: Aerosol indirect effects - general circulation model intercomparison and evaluation with satellite data, Atmos. Chem. Phys., 9, 8697-8717, doi:10.5194/acp-9-8697-2009, 2009.

Rasulov, B., Hüve, K., Bichele, I., Laisk, A., and Niinemets, Ü.: Temperature response of isoprene emission in vivo reflects a combined effect of substrate limitations and isoprene synthase activity: A kinetic analysis, Plant Physiol., 154, 1558-1570, doi:10.1104/pp.110.162081, 2010.

Riipinen, I., Pierce, J. R., Yli-Juuti, T., Nieminen, T., Häkkinen, S., Ehn, M., Junninen, H., Lehtipalo, K., Petäjä, T., Slowik, J., Chang, R., Shantz, N. C., Abbatt, J., Leaitch, W. R., Kerminen, V.-M., Worsnop, D. R., Pandis, S. N., Donahue, N. M., and Kulmala, M.: Organic condensation: a vital link connecting aerosol formation to cloud condensation nuclei (CCN) concentrations, Atmos. Chem. Phys., 11, 3865-3878, doi:10.5194/acp-11-38652011, 2011.

Schuh, G., Heiden, A. C., Hoffmann, T., Kahl, J., Rockel, P., Rudolph, J., and Wildt, J.: Emissions of volatile organic compounds from sunflower and beech: Dependence on temperature and light intensity, J. Atmos. Chem., 27, 291-318, 1997.

Šimpraga, M., Verbeeck, H., Demarcke, M., Joó, E., Pokorska, O., Amelynck, C., Schoon, N., Dewulf, J., Van Langenhove, H., Heinesch, B., Aubinet, M., Laffineur, Q., Müller, J. F., and Steppe, K.: Clear link between drought stress, photosynthesis and biogenic volatile organic compounds in Fagus sylvatica L., Atmos. Environ., 45, 5254-5259, 10.1016/j.atmosenv.2011.06.075, 2011.

Sitch, S., Cox, P. M., Collins, W. J., and Huntingford, C.: Indirect radiative forcing of climate change through ozone effects on the land-carbon sink, Nature, 448, 791-794, doi:10.1038/nature06059, 2007. 
Spracklen, D. V., Bonn, B., and Carslaw, K. S.: Boreal forests, aerosols and the impacts on clouds and climate, Philosophical Trans. Royal Soc. A - Mathematical Physical and Engineering Sciences, 366, 4613-4626, doi:10.1098/rsta.2008.0201, 2008.

Spracklen, D. V., Jimenez, J. L., Carslaw, K. S., Worsnop, D. R., Evans, M. J., Mann, G. W., Zhang, Q., Canagaratna, M. R., Allan, J., Coe, H., McFiggans, G., Rap, A., and Forster, P.: Aerosol mass spectrometer constraint on the global secondary organic aerosol budget, Atmos. Chem. Phys., 11, 12109-12136, doi:10.5194/acp-11-12109-2011, 2011.

Sturrock, R. N., Frankel, S. J., Brown, A. V., Hennon, P. E., Kliejunas, J. T., Lewis, K. J., Worrall, J. J., and Woods, A. J.: Climate change and forest diseases, Plant Pathol., 60, 133-149, doi:10.1111/j.1365-3059.2010.02406.x, 2011.

Topping, D., Connolly, P., and McFiggans, G.: Cloud droplet number enhanced by co-condensation of organic vapours, Nature Geosci., 6, 443-446, 2013.

Trenberth, K. E., Jones, P. D., Ambenje, P., Bojariu, R., Easterling, D., Klein Tank, A., Parker, D., Rahimzadeh, F., Renwick, J. A., Rusticucci, M., Soden, B., and Zhai, P.: Observations: Surface and atmospheric climate change, in: Climate change 2007: The physical science basis. Contribution of working group i to the fourth assessment report of the intergovernmental panel on climate change, edited by: Solomon, S., Qin, D., Manning, M., Chen, Z., Marquis, M., Averyt, K. B., Tignor, M., and Miller, H. L., Cambridge University Press, Cambridge, United Kingdom and New York, NY, USA, 2007.
Tsigaridis, K. and Kanakidou, M.: Secondary organic aerosol importance in the future atmosphere, Atmos. Environ., 41, 46824692, 2007.

Tunved, P., Hansson, H. C., Kerminen, V. M., Strom, J., Dal Maso, M., Lihavainen, H., Viisanen, Y., Aalto, P. P., Komppula, M., and Kulmala, M.: High natural aerosol loading over Boreal forests, Science, 312, 261-263, 2006.

Tunved, P., Strom, J., Kulmala, M., Kerminen, V. M., Dal Maso, M., Svenningson, B., Lunder, C., and Hansson, H. C.: The natural aerosol over northern europe and its relation to anthropogenic emissions - implications of important climate feedbacks, Tellus B, 60, 473-484, 2008.

Twomey, S.: Influence of pollution on shortwave albedo of clouds, J. Atmos. Sci., 34, 1149-1152, doi:10.1175/15200469(1977)034<1149:tiopot>2.0.co;2, 1977.

Weber, R. J., Sullivan, A. P., Peltier, R. E., Russell, A., Yan, B., Zheng, M., de Gouw, J., Warneke, C., Brock, C., Holloway, J. S., Atlas, E. L., and Edgerton, E.: A study of secondary organic aerosol formation in the anthropogenicinfluenced southeastern United States, J. Geophys. Res., 112, D13302, doi:10.1029/2007JD008408, 2007. 